\title{
At the University but Not of the University: The Benching of Willis Ward and the Rise of Northern Racial Liberalism
}

\section{Tyran Kai Steward}

\begin{abstract}
No Northern state university prohibits the enrollment of $\mathrm{Ne}$ groes, although a few practice minor forms of discrimination once they are enrolled. This is often a matter of individual prejudice rather than of official policy. ${ }^{1}$
\end{abstract}

The racial prejudice encountered by the University of Michigan's black lettermen during the first half of the twentieth century was entwined into the nation's fabric: restaurants and hotels refused service to African Americans, landlords denied housing to black renters, and employers rebuffed black job seekers when it came to postgraduation professional opportunities. "They [black Americans] were IN America but not OF it," remarked one writer recalling the racial exclusion that marked the era. Similarly, Dan Kean, a former tennis player at Michigan, reached the same conclusion about his and other African Americans' sense of social isolation in Ann Arbor that had been drawn about the racial restrictions placed on black life in America. "If you want to know what it is was like then I'd have to say black students were AT the University but not OF it."2 Kean's observation exposed the racial marginalization that black students confronted at the University of Michigan. Although African Americans began enrolling at the University of Michigan in the early 1850s, reflecting the early move toward integration in some areas of the North, discriminatory racial practices prevailed. White northern leaders supported race-neutral laws as they 
were compelled by both black and white activists to better manage the region's race relations. They embraced northern racial liberalism; that is, they espoused the idea that all Americans, regardless of race, were politically equal. Yet they resisted the belief that the state should exert its influence, arguing that the state cannot and indeed should not enforce racial equality by interfering with existing economic and social relations. The result was predictable: African Americans were integrated in parts of the North, but the shift toward race-neutral laws as well as legal and legislative remedies did little to diminish the stark racial inequalities they were forced to endure. Segregation and stratification withstood racial liberalism and the pro-integration ethos that accompanied it. ${ }^{3}$ At Michigan, lodging restrictions, institutionalized racial quotas, and racist ridicule from professors in the classroom, among other forms of racial prejudice, stood as salient reminders to the school's small black population of the gulf between their integration into a northern white institution and their attainment of full equality. ${ }^{4}$ Inclusion had its limits.

Whereas Kean summed the experiences of all black students at the University of Michigan, nowhere was the battle for full inclusion more fraught than in sport. Unwritten quotas, or "gentlemen's agreements" as they were commonly known, shaped the racial etiquette in athletics at Michigan and many other northern universities. ${ }^{5}$ Qualified black athletes were segregated from participation, especially in football and basketball. In other sports like swimming, gymnastics, and wrestling, they were unable to start joining those teams until the late 1950s and early 1960s when a newer wave of Michigan coaches began to discard the unwritten quota system for African Americans. In baseball, though Michigan's door was swung wide open by Moses "Fleetwood" Walker in 1882, only seven black men lettered in the sport, while no black athlete was permitted to play golf. ${ }^{6}$ In tennis, Kean became the second of only two African Americans to earn a letter in the sport in the university's history when he did so in 1934, following behind Henry Graham, who first achieved the honor in 1928. These racial constraints on black participation aside, the chasm between integration and inclusion that marked life for black athletes at the university likely imbued Kean's perception that African Americans had not been granted full acceptance. Nowhere was this gap between integration and inclusion more visible to Kean than during his senior season in 1934 when the university experienced its most embarrassing racial incident - the benching of Willis Ward, an African American football star and three-time all-American in track and field.

On October 20, 1934, Ward, who roomed and teamed with future U.S. President Gerald Ford, was benched in a game against Georgia Tech because of his race. Georgia Tech, a southern school, had a "Jim Crow" clause-in keeping with the segregationist dictates of the South - that prohibited its allwhite squads from competing against integrated northern teams. When Georgia Tech learned of Ward's presence in the Wolverines lineup, W. A. Alexander, the team's head football coach, promptly advised Michigan athletic officials of the racial customs in the South. "Public sentiment in the southeastern con- 


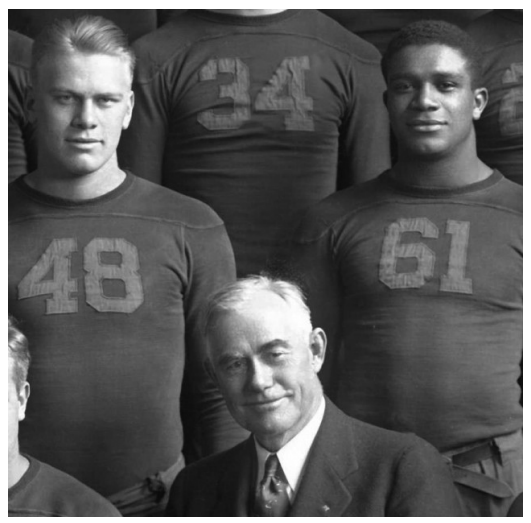

Figure 1: Gerald Ford, Willis Ward, and Fielding Yost pictured together for the team photograph in 1934. Courtesy of Brian Kruger, Stunt3 Multimedia.

the sideline. The University of Michigan was also complicit. Yost, who had his own motives for benching Ward, scheduled the game at least a year in advance despite knowing Tech's position on the race issue. Although Alexander volunteered to cancel the game to avoid the risk of putting "Michigan in an embarrassing situation" should an understanding not be reached, Yost assured the southern coach that Ward would not play. To worsen matters, Ward was banned from entering the stadium. Ward's benching, therefore, was also a part of Michigan's own Jim Crow tradition. ${ }^{7}$

A significant body of scholarship has examined the history of Jim Crow primarily within intercollegiate athletics in the South. ${ }^{8}$ This article, in contrast, provides an opportunity to examine the interplay between race and sport in the North. Specifically, it depicts the racialized social order maintained by the University of Michigan during the twentieth-century interwar period. Studying race relations through the lens of sport is beneficial since athletics has been characterized historically as an avenue of both racial integration and social mobility. Ward's benching, however, complicates that history and demonstrates how societal racial barriers were reconstructed in intercollegiate athletics. Ward's benching also emphasizes the role that sport performed in the structuring of racial exclusion as athletic arenas, like railroads, schools, restaurants, movie theaters, and other public sites, helped construct what historian Grace Elizabeth Hale has termed the "culture of segregation." Scholars have demonstrated over the past twenty years that this "culture of segregation" was not immune to the North, challenging the South's primacy in our understanding of the black freedom struggle. Historians have shown through studies of education, employment, housing, and policing that a northern version of Jim Crow existed 
with racial dramas that occasionally bore resemblance to the racial clashes and struggles occurring in the American South. This study builds on those studies of Jim Crow in the North and the larger "black freedom studies" work that have attempted to remove the South as the metanarrative of race relations discourse. The critical intervention is that this study shifts the civil rights era timeline back to the twentieth-century American interwar period and brings the relatively unexplored world of sport into historical focus. In essence, this article reveals how racial exclusion, hierarchy, and strife encroached on the quotidian realm of college sport just as it emerged in the fine-grain materiality of everyday black life. I especially focus on the Midwest and argue first that efforts to prevent black athletes from fulfilling their athletic quests expose how northern institutions maintained separate and unequal practices while not possessing the same legal underpinnings that existed in southern states. Where college football teams in the South were completely segregated and the color line was never crossed, northern officials relied on a variety of racial schemes, such as gentlemen's agreements, to deny black athletes full inclusion. Additionally, I contend that the opposition that black athletes faced reveals how northern schools actively engaged in constructing racial barriers that constrained black performance and compelled these players to exceed the standard athletic expectations just to earn opportunities to participate in sport. According to John Behee, black athletes had to be "superspades" - they had to be sensational from day one, displaying innate and rare physical abilities that justified their inclusion. ${ }^{10}$ The few black athletes who were deemed exceptional, however, often confronted racist epithets and violence by white fans, officials, and players. Finally, I uncover the shortcomings of northern racial liberalism. Northern states passed laws that granted black northerners political rights, yet without state intervention, discriminatory racial practices superseded the statutes that mandated political equality. This lack of enforcement carried over into northern universities where black athletes on integrated teams, like Ward, frequently encountered other de facto racial tactics that prevented them from achieving their goals of full equality in sport.

\section{Breaking Michigan's Color Barrier}

George Jewett broke the University of Michigan's pigskin color barrier in 1890, just a year after William Henry Lewis and William Tecumseh Sherman Jackson integrated college football at Amherst. Michigan's decision to allow Jewett to play influenced other pre-Big Ten schools to permit African American players on their respective teams. ${ }^{11}$ In 1891, Fred D. Patterson, who emerged as America's first black automobile manufacturer, joined the Ohio State University football team. ${ }^{12}$ Two years later, Preston Eagleson suited up for Indiana. Yet Michigan's early efforts to integrate its athletic squads and to sway other nearby, northern institutions to follow accordingly dissipated quickly. When Jewett left Michigan to attend Northwestern in 1893, having been deprived of the privilege to study medicine while simultaneously playing football, the university pivoted 
toward veiled practices that kept black competitors from donning the maizeand-blue uniform. Michigan did not recruit a single African American football player after Jewett's departure, and only one black athlete appeared on any of Michigan's other sports teams toward the end of the decade..$^{13}$

The hiring of Fielding H. Yost hardened the school's post-Jewett exclusion of black gridiron gladiators. When Michigan's first athletic director, Charles Baird, appointed Yost as the head football coach in 1901, it ended whatever opening African Americans might have had to play for the team. ${ }^{14}$ Yost was a native of Fairview, West Virginia, a northern town near the Pennsylvania border and closer to Ohio than to any place in the South. But there was no doubting it-Yost was a southerner. He was born six years after the end of the Civil War, and his father, Parmenus, served as a surgeon under Robert E. Lee. Further, his syrupy pronunciation of the school's name as "MEE-she-gan" betrayed his distinctive southern patois. ${ }^{15}$ His unwilling attitude toward utilizing African American talent to excel in sport was every bit the de rigueur of southern life where the 1896 Plessy decision fortified Jim Crow and created an unfavorable racial climate for black southerners. The rigid racial restrictions placed on black life in the South carried over into athletics, where African Americans were fully segregated from the playing fields - a racial prohibition that lasted into the early 1970s. The rise of southern administrators and coaches at colleges above the Mason-Dixon Line transformed campus race relations and drove northern universities to fall into the same pattern of discrimination against black athletes as their Confederate counterparts. Yost's arrival at Michigan, likewise, drove the school to follow this pernicious, racial precedent. ${ }^{16}$ Yost saw that he could win without black inclusion. Alongside his proficiency for developing young men into champions, often pressing his team to play better and faster with his constant "hurry up" roars, Yost transported southern-style Jim Crow to his new coaching gig in Ann Arbor. For the next twenty-five years, he rebuffed every attempt by black football players to integrate his vaulted squads.

Yost persistently ignored recommendations by Michigan alumni who pleaded for him to allow select black football recruits opportunities to vie for spots on various Wolverine rosters. In 1904, a compelling case was made on behalf of Abner Powell, dazzling phenom from Salt Lake City. He was alleged to have been able to run one hundred yards in ten seconds. The Big Blue alum said of Powell, "This young man is a human whirlwind ... the equal of Heston ... a thorough gentleman, always knows his place ... fine punter." ${ }^{\prime 17}$ But such attributes, which would have made Powell an ideal recruit had he been white, were shrugged off by Yost, who did not bother even to scout him. Toward the end of his coaching tenure, Yost tolerated having Belford Lawson, a talented black halfback from Roanoke, Virginia, engage in workouts with the reserve team. The reserves squared off in intrasquad practice events against the varsity team and were tasked with grooming the latter for real football games against other Big Ten and northern institutions. A press clipping in September 1923 highlighted Lawson's prowess on the field during a preseason scrimmage be- 
tween a "blue" squad and a "red" squad. "Lawson, colored halfback on the red, demonstrated his ability at breaking up passes, knocking them down with great regularity," the Detroit Free Press article reported. ${ }^{18}$ But Yost remained vehemently opposed to sanctioning black participation on the varsity, and Lawson was not granted any racialized immunity. Lawson was skillful enough to knock down passes thrown by the quarterback of a national championship team but not deemed good enough to take the field during regular-season competition. According to John H. O'Brien, "It was pretty well understood that Yost would not have a black on any football team he coached, although he did not object to their participation in other university sports. Football was something else again."19 The West Virginian effectively halted the university's already shaky commitment to integration on the gridiron, and not a single African American "ever played varsity football for him." 20

Willis Ward was quite familiar with Yost's unwritten policy barring African Americans from becoming members of the Michigan lineup. The scuttlebutt on the school's refusal to play black football players was well known throughout the state with black athletes forced to quit football and to settle for track and field. ${ }^{21}$ Although Yost had retired from coaching after the 1925-1926 season, his role as the university's athletic director belied every impression that his successors might put an end to the de facto segregationist custom of excluding black football players that he implemented. Olympic hero Eddie Tolan, the "world's fastest human," encountered Yost's effect on the Wolverine coaching staff. Tolan, who tried out for the team in 1927, was initially given permission to play. But on the third day of practice, E. J. Mather, the freshman football coach, notified Tolan of the team's decision to keep him off the squad, ruining any prospect Tolan had of becoming Michigan's second black varsity letterman. "Some coaches are disagreeing on your chances," Mather explained to a crestfallen Tolan. "Some of them think you shouldn't be allowed to play. I'd be tickled to have you but I'm afraid I'm going to be outvoted." Mather's apprehension with respect to campaigning aggressively for Tolan to be on the team exposed his declining influence with the university's other athletic officials. He battled cancer throughout the 1927 season and was forced to step down from his head coaching duties on the school's basketball team. But the unwillingness by Michigan coaches to undermine Yost's unbendable authority loomed larger in preserving the school's routine of fielding an all-white football squad. The Michigan athletic personnel grasped the racial narrow-mindedness that infused their boss's outlook concerning the use of African Americans. None of them, to a man, wanted to be held culpable for prospering Jim Crow. But Yost was a leviathan in their eyes, well regarded as one of the country's finest and most influential coaches. Earning his respect superseded any penchant for fairness, especially since the potential of acquiring his blessings could eventually lead to a major coaching promotion. Thus, Yost's long-standing racial diktat that black athletes be withheld from playing football was politely obeyed. They demanded that every black player be a "superspade"-exceptionally gifted and 
good enough to start day one or be kept from competing. In the interim, the staff made every effort to explain that "Michigan did not discriminate" so as to hide any guilt of racial prejudice. For Tolan, he was simply not good enough just like the other African Americans who had tried to make the Michigan roster had been told. The team promptly "took away Tolan's football uniform and handed him a track suit in exchange," one of the few sports where Yost raised no objections to fielding black athletes. ${ }^{22}$

Ward observed the treatment of Tolan and other black superjocks by Michigan. Four years later, he prepared to attend Dartmouth. Nestled on the Connecticut River in Hanover, New Hampshire, Dartmouth gained somewhat of a reputation for offering bona fide tryouts to black competitors. Michigan's integration of its football team had preceded Dartmouth by twelve years. But after Matthew Washington Bullock joined the "Big Green" roster in 1902, becoming only the second African American in the Ivy League to do so, Dartmouth devoted its attention to enrolling other black standouts to end the college's color line in athletics. The older brother of legendary Fritz Pollard, Leslie, played halfback for the school during a period characterized as the "nadir" of American race relations. This unprecedented display of racial egalitarianism, which ran counter to the prevailing racial trends within the country, amazed Ward, whose simple desire was to play for an institution not averse to utilizing black athletes. He reasoned, "If a school has a reputation of not utilizing an athlete because he is black, then you will go to the school that doesn't." The consensus view was that Dartmouth offered a welcoming place to African Americans, and Ward discerned he "would be happier [there] as it was somewhat more liberal" than the university located approximately one hour to the southeast from his home in Detroit. When one Michigan coach and Dartmouth alum, aware of his alma mater's willingness to treat black football players fairly and Michigan's ban on them, pushed for Ward to head east to the rural New Hampshire school, it only strengthened the young man's resolve to leave the Midwest. ${ }^{23}$

Michigan head football coach Harry Kipke, however, felt strongly about Ward's skills on the field and urged his matriculation at Michigan. In the spring of 1931, Kipke approached Ward with a plan for getting him on the team. He visited the Ward home to meet with Willis and his father, Henry. He encouraged Ward to consider Michigan and tried to solicit Henry's help by promising the old man that his son "would never regret it." Conscious of the rebuttals that Henry and Willis might have regarding Michigan's established racial customs, Kipke summarily dismissed the concerns. He asserted that Michigan's racist rule, if there was such a thing, was one in which he did not take part. Kipke's sensitivity to the unease felt by the Ward family over Michigan's tradition of excluding black football players nearly won over Henry and Willis, both of whom saw him as a genuine, racial ally. ${ }^{24}$

But Kipke's pledge to curtail Yost's de facto rule proved daunting for the young coach from Lansing, Michigan. He witnessed firsthand Yost's impatience with Elton Wieman, who lasted only two seasons as Michigan's head football 
coach. Outside of being scapegoated by Yost for the team's poor showing, Wieman's complaint that the heavy-handed southerner never furnished him with complete control of the team jeopardized any possibility of his retaining his job. ${ }^{25}$ Wieman's outstanding role in working to help transform Michigan into a juggernaut neither diminished Yost's restlessness nor averted his decision to fire his former offensive line coach. Being a spectator to Wieman's demise only escalated Kipke's pessimism that he would be able to convince his mulish boss to acquiesce to letting Ward play for Michigan. He lacked Wieman's coaching clout, and Yost was undoubtedly not going to be persuaded by his newest minion. Sure, Kipke was a beloved Yost recruit who lettered in three sports and captained Michigan's undefeated 1923 national title team. But his athletic resume did not erase his relative coaching inexperience or impart to him the know-how needed to maneuver single-handedly against the intimidating West Virginian. His greenness on the field aside, whatever remaining amounts of leverage he may have possessed were sliced away by the unrelenting fear of being laid off as the Great Depression shrunk college budgets and forced athletic departments to decrease expenses. Football coaching staffs whose salaries had once been impervious to university-wide spending cuts now found themselves among the unemployed. ${ }^{26}$ Kipke could ill afford to test his eminence's say-so over the matter and risk being fired. Thus, to integrate Michigan's lineup, Ward required a higher authority than the docile Kipke, who had spent the previous decade learning closely under Yost's tutelage while trying to gain his admiration.

Circuit Court Judge Guy Miller possessed the legal muscle needed to overturn Yost. Word of Ward's decision to register at Dartmouth had already been leaked by the press. Still, Miller's motivation to help Ward integrate the Michigan football team grew after he was contacted by fretful school officials who notified him that "Michigan and Yost did not want black football players." Miller, along with fellow Third Circuit Court Judge DeWitt H. Merriam, discussed the matter with James Murfin, a regent of the University, and Fred Matthai, who served as president of the University of Michigan Club in Detroit. Both men backed Kipke's recruitment of Ward and had made their own overtures to him to gauge his interest in attending Michigan. Ex-Governor Alex Groesbeck, a graduate of Michigan Law School, also espoused support for Ward's enrollment. No stranger to controversy himself, Groesbeck had once denounced the $\mathrm{Ku}$ Klux Klan over their staunch resistance to his reelection bid and his refusal to outlaw private education. His advocacy on behalf of Ward was, therefore, refreshing. Together, these men convened to pinpoint a strategy to topple Yost. But it was Ward who permeated their dialogues. In their conversations, they wondered, "Well, why doesn't this kid go to Michigan?" Despite Yost's racism, the prevailing conviction by this ad hoc yet powerful assemblage was that Michigan's bigoted customs could be jettisoned if they had a gifted athlete who possessed the right character and deportment to challenge the university's exclusionary practices. Given his decorated athletic performances in high school and quiet demeanor, Ward was presumed to be the player with the talent to 
win over indifferent white northerners whose racial apathy otherwise preserved the intolerance shown to black athletes. But to assure him that he was the man needed to oust Michigan's racial embargo, Judge Miller turned to Marshall Pepper for assistance, supposing that the black law clerk would appear credible to Ward. ${ }^{27}$

Miller assigned Pepper the responsibility of conversing with Ward, "one black to another," about the situation. But Pepper's racial tête-à-tête with Ward did not immediately convince the hesitant football star. Ward countered Pepper's appeals with a barrage of questions, none more crucial than the issue he raised about the practicality of attending school in Ann Arbor in spite of Michigan's practice of prohibiting black athletes. "Why should I go to Michigan if I want to play football? I can't play," Ward shouted. Pepper anticipated Ward's grievances. He and Ward were but two sides of the same coin — black men dealt the unjust hand of racial inequity. In spite of that, Pepper had managed to integrate an otherwise white world as a law clerk and deduced that with the strong backing and well-thought-out plans of his superiors, Ward could do the same in Ann Arbor. He insisted to a hesitant Ward that there were a group of men, including his own boss Judge Miller, who were ready to abolish Michigan's deplorable acts of racial exclusion. Pepper then advised Ward to meet with Judge Miller, who he claimed was adamant in his rejection of the university's separatist practices. Ward went to meet with Judge Miller at his chambers in the old circuit court building, though he only agreed to do so out of "a feeling of sympathy for the clerk, for whom it was important." ${ }^{28}$

The conference with Judge Miller was propitious. In response to the school's egregious color line, Miller grilled Ward on his eagerness to help dismantle Michigan's discriminatory practices. Miller posed to a reluctant Ward,

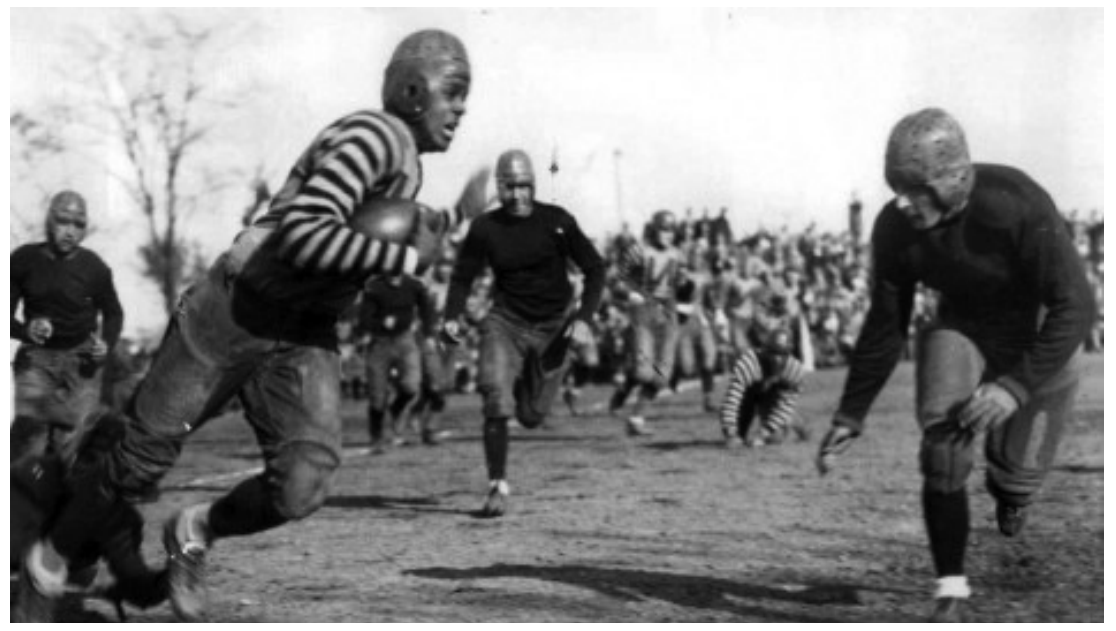

Figure 2: Willis Ward carries the ball for Northwestern High School. Courtesy of Burton Historical Collections, Detroit Public Library. 
"Well, if we can get an assurance that you will get a fair chance at Michigan, would you help us break this alleged tradition?" As Ward sat back in his chair, contemplating what he should do, the anxious judge went on. "We can't do it without help, and we need somebody who has the talent so they can't come back to us and say, 'Look, the kid just couldn't make it.' You know." Sensing that Ward was ready to give in, Miller, every bit the skilled litigator, presented a lastditched argument to win over the talented lad. "Your marks are high enough to indicate that you should be able to survive scholastically at Michigan. So why don't you help us help you?" His entreaty worked. Judge Miller's meticulous reasoning reassured Ward, who graciously agreed to break Michigan's racial barrier. ${ }^{29}$ With the endorsement of Murfin, Matthai, and Miller, Ward enrolled at Michigan to play football for Kipke. Yost was neither pleased with the decision to overturn his de facto policy of barring African Americans from playing football at Michigan nor pleased with the role Kipke performed in enlisting Ward's services. Yost reportedly came to blows with his young protégé. ${ }^{30}$

Ward relished in the opening to join the Michigan football team. "I went for it, and don't regret it," he ardently professed. To Ward, Judge Miller's ruling represented a good omen that the university's icy race relations had begun to thaw. This view was strengthened by his arrival on campus. If Ward held any skepticism that the racial climate had changed, then his first day at Michigan altered his lingering sense of disbelief. A blond, tousled-haired chap approached him and said, "You are Willis Ward. I am Jerry Ford from Grand Rapids." Running into a fellow Michigan athlete helped Ward feel comfortable during the all-important registration process at the Waterman and Barbour Gymnasium. That Ford introduced himself, on the other hand, made Willis feel welcomed. He described Jerry as affable and quickly saw in him a man with "no hard prejudices because of color."31 Ford's cited his upbringing in Grand Rapids as shaping his broad-mindedness. ${ }^{32}$ Ward recalled Ford as judging each person according to "character and general behavior"-qualities Henry Ward had worked hard to instill in his children. Ward and Ford became "fast friends," as Willis portrayed it, "and that was the way it was." Before long, they also became roommates for away games that took the Michigan team on weekend road trips against other Big Ten opponents. ${ }^{33}$

The year was 1931, a crucial moment in civil rights movement history. It was the same year that Olen Montgomery, Clarence Norris, Haywood Patterson, Ozie Powell, Willie Roberson, Charlie Weems, Eugene Williams, and brothers Andy and Roy Wright, or "the Scottsboro Boys," as they became known, were falsely accused of raping Ruby Bates and Victoria Price. That the incident happened in Ward's birthplace of Alabama was a sign of how vastly dissimilar the world in Ann Arbor seemed from life in the South. As eight of the nine young men originally charged with rape were preparing for their retrials with appeals to be heard in 1932, Willis Ward was diligently studying, swiftly becoming a household name in track and field as only a freshman, and gearing up for spring football practice to be held at the end of the school year when he 


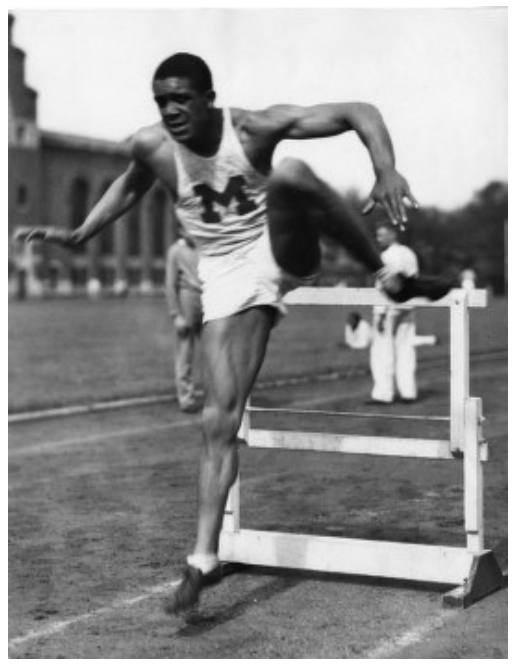

Figure 3: Willis Ward runs the hurdles for the Michigan Wolverines track team. Courtesy of Bentley Historical Library, University of Michigan. would finally get the formal opportunity to overcome Michigan's racial hurdle. And rather than have whites carry out a miscarriage of justice against him, those whom Ward met seemed sympathetic to his cause. Bob Miller, the son of Judge Guy Miller, offered Ward reassurance. "My father told me you were coming, and if you have any problems, let me know." Ivan Williamson, captain of the 1932 Michigan football team, greeted Ward with a similar message: "If you have any problems with anybody, let me know because we're prepared to take care of them." But no promises likely held as much sway with Ward as those from Harry Kipke, who, he claimed, "loved me as a boy" and "was determined to fight anyone who might try to hurt me because of race." Ward had neither any reason to distrust Kipke and the ther any reason to distrust Kipke and the others nor any inclination that these assurances would come under challenge. And given what to him looked like racial evenhandedness, he had no grounds to embrace his own father's cynicism that the supposedly benevolent white people at Michigan "are going to turn on you." For Ward, the proof was yet to come. ${ }^{34}$

\section{The Limits of Northern Racial Liberalism}

Henry Ward's anticipation that Michigan officials would turn on his son did not take long to be satisfied. As Michigan prepared for another season, Kipke wasted no time testing out the racial mettle of his lone black prospect. Among the young men vying for opportunities to prove they were ready to help lead Michigan back to athletic glory were rising sophomores Willis Ward and Gerald Ford. Freshmen were ineligible to play on the varsity, so both men had to wait their chance to earn a spot on the team. But having to sit on the sideline for a season was advantageous for the anxious lads, who were able to sharpen their skills. The varsity trained against the freshmen in preparation for their next opponent. The practices were grueling, the competition stiffer than what either Ward or Ford had each remembered during their prep days at Northwestern and South, respectively. Yet both men delighted in the snap-to-whistle intensity that transformed a customary exhibition into a spirited gridiron affair. They also treated the situation with the maturity expected of upperclassmen. Ward acknowledged the benefit of delaying the start of varsity-level play for freshmen. "There is a vast difference between college - that one year difference in a 
young man's age, at 18, 17, give or take a year," Ward opined. "It can make so much difference in his physical growth.... And you get out there as a freshman, you learn the system." Their eagerness to have Michigan scouts teach them how to compete against other Big Ten teams and the nonstop lessons from Coach Kipke as well as their freshman coaches on how to play with physicality readied them for the arduous battles sure to come against unyielding conference foes. ${ }^{35}$

Ford glimpsed "football [as] my ticket to college," while the fleet-footed Ward characterized athletics as a chance to get a first-rate education. "You go there for an education, and that's what the school is for. Athletics-although Michigan has been very successful in the athletic field, it's more renowned for its scholarship." ${ }^{\prime 36}$ Although they were fond of Michigan's intellectual tradition, Ford and Ward were also delighted to build on the institution's athletic achievements. After a year on the freshman football team, they were raring to go. Ward had wetted his feet on the track and field team. But there was nothing that compared to his putting on the maize-and-blue football uniform for the first time. Being a member of the Michigan Wolverines was special, something of an allure for young men throughout the state whose dream it had been to play in the Big House. They were spectators to stars like Benny Friedman and Bennie Oosterbaan. Fielding "Hurry Up" Yost, the country's most famed college football coach, was glimpsed by his peers as a living legend. And Michigan Stadium, fashioned after the majestic Yale Bowl, was unrivaled in its construction and magnificence. It featured the earliest innovation of the electronic scoreboard and sturdy columns and footings to enable the seating to be expanded beyond 100, 000. Such was Michigan's magnetism that Arthur Krause, Ford's principal at South High, became an ardent support of "Big Blue" despite being an alumnus of the University of Indiana. "The Wolverines," Krause was convinced, "were one of the finest teams in the land." Jerry Ford had professed his own adulation for Michigan in a letter he wrote to Coach Kipke, expressing his gratitude for being able to attend college at the school. "I've always wanted to be a student at the University since I was able to read about the prowess of their athletic teams." ${ }^{37}$

Ward's aspirations traveled beyond athletics and were forged in racial symbolism. Chiseled in Michigan's storied football past were the memories of both national titles won and celebrated turf wars against rival Ohio State, most ending in lopsided victory for the team fondly referred to as the "Victors." On any given Saturday, a crowd of 85, 000 fans, consisting of students, faculty, loyal alumni, and other devoted followers, packed Michigan Stadium to watch their team dominate some hapless opponent. But carved into-or, more appropriately, out of - these illustrious images were the tales of black gridiron gladiators who had woven their own achievements into the yarn of Michigan's pigskin glory. Outside of George Jewett, no other black athlete had lettered in football during the school's fifty-three-year involvement in the sport. Michigan's racial past had been fraught with inequity. The university never held an 
official policy excluding African American from enrolling at Michigan. Samuel Codes Watson enrolled as a medical student in 1853, fourteen years ahead of the decision by the Republican-led Michigan legislature to disband segregated schools in the state in response to the activism by African American parents and northern racial liberals. ${ }^{38}$ Black Michigan students, nonetheless, endured other de facto forms of separation once they arrived on campus that revealed the limitations that mere acceptance had for achieving racial fairness. On-campus lodging for African Americans exposed the boundaries of racial liberalism. In 1929, the Board of Regents proposed university-run housing for black women on Glen Avenue. African American activists, seeing this as an attempt at segregation, voiced harsh disapproval, and the proposal was dropped. Eleven years later, the administration forbade black students to live on campus, confirming the earlier belief of black protesters that the University of Michigan permitted segregationist practices in spite of its seeming commitment to racial integration. ${ }^{39}$ Northern race liberals were likely to oppose segregation on principle, though they proved unwilling to disrupt prevailing racial customs to promote full equality. They reinforced the existing racial hierarchy when African Americans clamored for equal access, leaving the few black students at Michigan, in this case, vulnerable to random discriminatory tactics. ${ }^{40}$ For example, Michigan's pioneering black enrollees faced a tougher time than lesser-qualified white students securing financial aid, were often met with racial humiliation in the classroom by their professors, and were vehemently discouraged from interracial dating despite the virtual absence of African American women on campus. ${ }^{41}$ The racial animus stirred over interracial dating is particularly revealing of the weaknesses of northern racial liberalism. The state repealed its miscegenation statute in 1883, forty-five years after it was first instituted. But racial practice overshadowed existing laws, and white men in the Midwest and North, wishing to protect primacy and property against the perils of racial intermixture, still maintained their aversion to interracial rendezvous. ${ }^{42}$ On campus, Michigan coaches were said to be the least tolerant of interracial trysts, and African Americans were dismissed from the team if they insisted on dating white women. Integration had provided a vital step toward equality, but for African Americans at northern institutions such as Michigan, it was not equality itself. It was a painful lesson in racial liberalism for black collegians that black southerners were forced later to learn in the aftermath of major legal and legislative battles won to curtail Jim Crow.

For the moment, Ward stood in stark contrast to Michigan's sordid racial history. He had been given the judicial go-ahead to join the football squad by Judge Guy Miller. For all his early accomplishments in track and field as a freshman, the notable accolades attained in years past by other black standouts, namely, Olympians DeHart Hubbard and Eddie Tolan, detracted from his own successes. In football, however, there was no robust black tradition of athletic dominance at Michigan to lessen the racialized significance of the occasion, sans George Jewett's dazzling displays during the long-forgotten early 1890s. 
As Ward stepped onto Ferry Field for spring practice, he wanted to demonstrate that he belonged. He ignored the anxieties expressed by Michigan track fans who worried he might get injured and blow his chance to be "the greatest track man to ever compete for the Maize and Blue." To Ward, his play on the football field, in spite of Yost's reluctance to embrace the use of black athletes, was essential to validating the strong push made by Judge Miller, Governor Groesbeck, and others to guarantee him the chance to join team. His performance could also dispel racial myths concerning African Americans' supposed inability to pick up the game. Ward knew all too familiarly the denigrating labels rooted in justifying white supremacy that were trademarked for black competitors. "And they used to say, the black kids are too dumb, you know, in basketball. . . . And in football." Although most of these racist stereotypes about black intelligence were concocted to conceal white aversion to social contact between black and white participants, Ward's feats on the field supplied evidence contrary to the notion that African American athletes were ham-fisted and unhurried learners who were qualified only to run track. As one press report summing up his decision to play football and risk injury read, "Ward would rather win an 'M' on the gridiron than to be an Olympic champion."

His debut with the team was splendid. The United Press provided details of the scrimmage. "Three young freshmen at the University of Michigan-Jerry Ford, of Grand Rapids; Russell Oliver, of Pontiac, and Willis Ward, Detroit Negro-displayed such brilliance during spring football practice that they are expected to become important cogs next fall in the Wolverine varsity eleven." If it had not been for the exceptional play of Ford, Ward would have been honored as Big Blue's most valuable returning freshman player. Ford won the Meyer Morton Trophy, awarded to the first-year man who demonstrated the "most improvement, best attitude, and greatest promise for the varsity." But it was Ward who electrified media correspondents present at the game with his tantalizing exhibition. One report filed later in July described him as "the outstanding athlete becoming

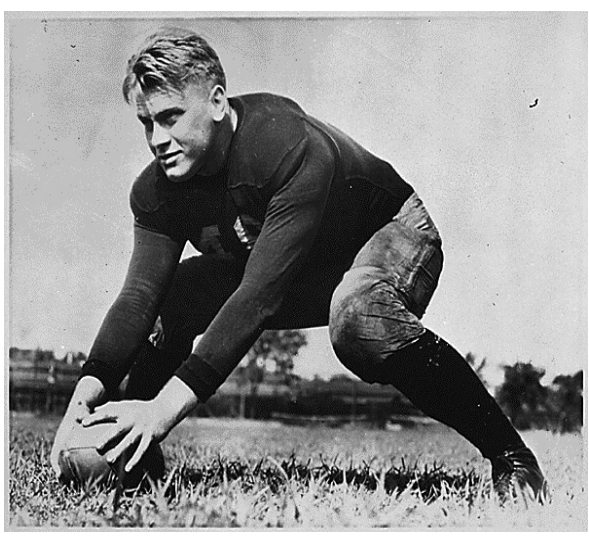

Figure 4: Gerald Ford hiking the football in 1933. Courtesy of Gerald R. Ford Presidential Library. eligible for play." 44 The tough task standing before Coach Kipke seemed to vanish with the superb performances put on by his top freshman recruits. Ward's impressive unveiling was particularly reassuring for his young head coach. Ford and Oliver, despite their notable feats, were destined to be backups. Ford, in fact, waited two full seasons before 
he was able to become the team's starting center, languishing behind all-American Chuck Bernard. Ward, on the other hand, was expected to become an immediate contributor. Kipke tested Ward's readiness, however, through a vicious act of racial cruelty. He summoned his team to pounce on the "giant negro." Kipke was later quoted as saying that he "ordered his veterans to pound [Ward] 'without mercy' during practice, so that if, at the end of the week he doesn't turn in his uniform, then I know I've got a great player." When Ward kept his jersey and pants and showcased his talents in thrilling fashion, Kipke discerned that he had located a "superspade" - a gifted black athlete who not only could be instantly special on the field but who also was able to lessen the racial friction that was predicted to emerge over his involvement on the team. ${ }^{45}$

This kind of racial ruthlessness, coming out of Kipke's mouth, tasted southern. It was customary of men like Yost to display such pitiless and prejudiced attitudes. Yet Kipke's virtual bounty on Ward was Jim Crow North. Kipke unmasked the North's segregationist facade where African Americans were tolerated but still bumped into racial malice and mocking. Black northerners were not acquainted with the tangible "white only" signs that delineated private and public space as their black counterparts were accustomed to in the South. Even so, they were familiar with racial boundaries that were just as sinister and possibly more stable. Informal segregation was regularly practiced by white northerners in Michigan, and African Americans could face significant consequences if they crossed over these invisible boundaries. ${ }^{46}$ White northern liberals disregarded the relationship between social and spatial exclusion. Geography affected American race relations in the North and narrowed black and white interaction. The pervasiveness of residential racial segregation shaped social dealings and zoned the school choices African Americans possessed not only to pursue integration but also to decide on where to educate their children. These hidden geographical dividing lines were not novel creations but were structured through decades of racial separation and through the sanctioned practices of redlining and restrictive covenants, steering and signs, accepted or actual, which conveyed "white only." ${ }^{47}$ White race liberals especially did not express themselves in explicitly racist terms, but they embraced gradualism in a way that made the established racial order nearly shatterproof. ${ }^{48}$ Because these de facto racial practices were apparently impenetrable to legal or legislative overturn, African Americans in the North discovered a fleeting sense of equality. Ward's participation on the varsity was hardly a sign that white Americans accepted him just as his father presumed would not be the case.

As a "superspade" of his time, Ward was compelled to outperform whites and outrun racial violence. The sturdy gestures from Kipke and some of his teammates that allayed his fears of being exposed to racial torment softened. Ward's eyes, even if partly open, now concentrated more steadily on the veiled discriminatory acts that African Americans tackled in Michigan. Yet he was reluctant to abandon his opportunity to play for Michigan. He shrugged at the rough treatment that was ordered against him, portrayed Kipke as evenhanded, 
and spotlighted benevolent acts that the coach and other white university officials performed on his behalf. "Kipke," he declared, "was one of the fairest men I knew-ever." ${ }^{49}$ Fielding Yost, in spite of his bigotry, also appeared reasonable in Ward's recollection. Yost allowed Ward to remain with his team when traveling, breaking widespread customs. Colleges routinely gave African Americans who participated on integrated teams a pittance and located some reputable black family to lodge them on the road. "Now this was accepted around the Middle West anyway," Ward stated, "and therefore the kid wasn't with the team overnight." ${ }^{50}$ Black athletes who traveled with an all-white squad, unsurprisingly, were arbitrarily debased and treated as a second-class citizen when it came to housing. DeHart Hubbard, the first black athlete at Michigan to make a traveling squad in the twentieth century, recalled the embarrassment of not being allowed to eat with his team in a private dining room at a Chicago hotel in 1924. A discomfited Hubbard bitterly stated, "I suppose that was part of the racially accepted pattern of the time. ${ }^{\circ 1}$

Eddie Tolan and Booker Brooks might only wish they were as lucky as Hubbard. They were required to stay at the black YMCA. If the degradation of having to find lodging in a YMCA away from their teammates was not enough, Tolan and Brooks encountered more shame on rejoining their teammates at the hotel. They were chided by the hotel clerk for using the front entrance and cruelly advised not to do so again. It mattered neither to the hotel clerk nor to Michigan officials that Tolan had won two Olympic victories or that the governor of Michigan named a day in his favor as a symbol of America's pride in this young man's athletic accomplishments. John Behee summed up the indifference shown toward Tolan and Brooks, concluding that "to the hotel clerk in Chicago, whose attitude reflected the national persuasion, any black wanting accommodations was just another 'nigger." Behee's analysis neglected the University of Michigan's complicity in treating Tolan and Brooks with racial contempt. No representative from Michigan objected to the hotel clerk's racial disparagement of two young men or suggested that the attendant's actions were outside the purview of the racial opinions held by the preponderance of the school's athletic officials, namely, Yost. ${ }^{52}$

Henry Graham also found traveling to be arduous, revealing a more tangible illustration of northern schools' culpability in helping to perpetuate Jim Crow practices throughout the region. Graham, the number two man on Michigan's 1927 tennis team, acknowledged that "Negroes were barred from the better hotels and, of course, that's where the Michigan teams stayed." One of the most disconcerting incidents for Graham came during a trip to Minneapolis for a tennis match against the University of Minnesota. One of his teammates was informed that African Americans were not allowed to stay at the hotel and told Graham that he needed to leave. The night clerk claimed that if the black tennis star stayed, "all the guests would walk out." He recalled, "The captain came to me and said, 'Graham, we've got a problem. I'm from Iowa and I don't know too much about colored people. I've had very little contact and I really don't 
know them. I've lived on a farm and there were none near. There were none in the schools I attended. But I have no prejudices. I think you're a fine person and I'm behind you, but I'm not going to fight the color question." ${ }^{53}$ His teammate's apathy augmented Graham's humiliation. While Graham's comrade alleged that he had not held any prejudices, he was still unwilling to challenge the unsanctioned racial intolerance that black athletes endured on the road. In a broader context, whites' avoidance of dealing with the "color question," what W. E. B. Du Bois called the "major problem of the twentieth century," fueled the explosion of a northern version of Jim Crow. White race liberals who rhetorically asserted opposition to racial prejudice and who advocated for political equality were hesitant to put white privilege at risk by defying racism. ${ }^{54}$ In these moments, black athletes, like African Americans throughout the country, were reminded of the saliency of white supremacy.

By early 1932, Michigan coaches began to confront the problems of lodging black athletes away from the rest of the team. "Kipke and Michigan busted that rule," Ward proudly stated. He continued, "Kipke said that this kid was a member of my team, and I want him to feel a part of the program and not have his feelings hurt." Kipke was adamant that Ward board with the team and pushed Yost to alert hotels that a black man was on varsity and that the team did not want any embarrassment at registration time. Ward believed that the bigoted Yost stepped out of racial character to defend him during a team trip to Chicago. Although Big Blue relied on the Palmer House Hotel for lodging through the years, the hotel's management was unreceptive to the requests made by Kipke for Ward to stay there. When they declined to alter their policy, "Yost flip-flopped from being a segregationist." Ward remembered Yost saying, "Well, we have been staying at this hotel since 1900 . We will pull every team that we have and not stay. . . . And I am going to see if I can't get other Big Ten schools to also not stay at your hotel." Officials at the Palmer House Hotel relented. The Depression had already "rocked them well" and "shook them in the pocketbook," Ward verified. ${ }^{55}$ Yost's stand gratified Ward. "He [Yost] was a strong supporter of me." Willis overlooked the likelihood that Yost's posturing was an indication of the athletic director's own mortification with being openly rebuffed despite his own misgivings concerning Ward's presence on the team. Yost, according to some observers, allegedly detested having Ward in the Michigan lineup and cooperated with Kipke only because of the pressure Judge Miller had put on him. Not to be slighted, Yost demonstrated his influence and power by forcing the Palmer House Hotel to honor his demands. His racial grandstanding notwithstanding helped Ward integrate the hotel. "Aside from Marian Anderson, I was the second black to stay in the hotel as a guest in 1932," Ward remembered. The same thing occurred in Columbus, Ohio, when the Wolverines traveled there to play the Buckeyes during Ward's junior year. He integrated National Hotel, where William Henry Harrison, a presidential candidate, had spoken in June 1890. "And the help, many of them black, tele- 
phone operators, waiters and all, you would see them coming and looking to see: There he is," Ward giddily reminisced. ${ }^{56}$

Ward immersed himself in the pleasure gained from being a racial pioneer. He also absorbed the implications attached to his racial groundbreaking, at least at the outset. His creation of opportunities for other African Americans was encouraging. As a senior during Jesse Owens's sophomore year, Ward appeared ready to establish a racial legacy. He helped his Buckeye rival integrate the Indianapolis Club when both went to partake in the Butler Relays. Ward was initially turned away. The desk porter explained to the track team manager that Ward was not permitted to stay. When the manager conveyed the hotel's position to Michigan track coach Charlie Horton, Horton immediately threatened to leave. Horton shouted, "Well dammit, we will turn this team around and go back to Detroit." Minutes later, the manager, "beaming like a devil," according to Ward, came to the Michigan track champion and said, "Willie, here is your key." Ward then pushed Owens, who had also been refused lodging, to brave the hotel's Jim Crow policy. "So I told him, I said, 'Jesse, you had better get your coach, Larry Snyder, because I am here.' So Jesse gets mad, and he calls his coach ... and he beefs on him. The next thing I know, here comes Jesse with his key. Whee! We are in!" 57

In reality, Ward was not in. These moments steeped in northern racial liberalism signaled racial progress, but they were hardly a precursor to African Americans gaining full inclusion. Michigan's white administrators and coaches were barely on the verge of completely accepting Ward's presence on the football team and certainly were not ready to extinguish the smoldering flames of racial injustice. As Ward heard the tale, "[Harry] Kipke would be down at the Detroit Club or the DAC [Detroit Athletic Club] or the University Club with a bunch of whites saying: 'Well, what are you using a Negro for? Michigan was great without 'em!'"58 In spite of his vast athletic gifts, there was little Ward could do to convince most white northerners and his superiors, especially Yost, that he fully belonged. He conquered the track and field and was dubbed Michigan's one-man track team. On the football field, he led Michigan to consecutive national titles, earning honorable mention all-American honors his junior season. In December 1933, he finished as the runner-up to Duane Purvis of Purdue for the Associated Press Big Ten Athlete of the Year. According to an Associated Press wire, Purvis edged Ward "by the slender margin of two votes." Ward's talents were apparent to the conference coaches and sportswriters who voted. "Ward, in addition to his feats in track, was one of the bright stars of Michigan's championship football team this fall. Fast and rangy, he was classed as one of the finest wingmen in football." Yet the man who drew constant praise and collected several accolades for his ability to evade defenders on the field was unable to elude Jim Crow. By the summer of 1934, only months before the start of his senior year, team officials notified Ward that he was going to be benched in the Georgia Tech game. 
Benching emerged as one of the most prevalent approaches northern schools exploited to snub African Americans when segregated white opponents rebuffed playing against a "Negro." ${ }^{59}$ In most instances, northern universities deployed this de facto tactic in intersectional contests with southern teams as coaches and other athletic officials popularized the use of gentlemen's agreements. These often unwritten pre-arrangements assured southern institutions that the much ballyhooed games against northern schools were to be played Jim Crow style. The "Jim Crow clause," as these gentlemen's agreements were dubbed, was so customary that, in a few cases, schools began writing this stipulation of benching black players into contracts that were signed years in advance. ${ }^{60}$ "Such benchings," according to Michael Oriard, "became increasingly common ... as more major football schools in the North integrated their teams, and as universities from all regions were more willing to travel to other areas of the country in quest of national prominence." ${ }^{\prime 1}$ Occasionally, black players could also be asked to sit out games with northern opponents. Although a seldom practice, the custom far preceded the routine of benching African Americans in games between teams in the North and the South. As early as 1903, DePauw, a Methodist school in Indiana, requested that nearby Wabash College sideline its lone African American player, Samuel Simon Gordon. DePauw dropped its demands only after "several prominent Methodists . . . appeared [and] and besought the young men not to disgrace a Christian college by drawing the color line, and protested against what they denounced as cowardice and barbarism." Although DePauw agreed to play the game, their strong flirtation with Jim Crow portended a negative sign of things to come for other northern institutions. ${ }^{62}$

By the 1930s, the North's flirtation with Jim Crow had moved beyond intrigue to full racial courtship. The widespread practice of benching black athletes reflected the northern racial hierarchy. Far from establishing a precedent, Ward's benching followed the pattern of racial exclusion established by other northern institutions. While most of these bans on black participation occurred in games played in the South, an unsettling trend emerged as more northern schools began to yield to southern demands even on the home fields of northern institutions. ${ }^{63}$ Ward became one of the first African Americans to be benched on northern soil in an intersectional game with a southern team, chipping away at the simplified stories of racial progress and displaying the limitations of northern racial liberalism.

\section{The Benching of Willis Ward}

In the weeks leading up to the October game between the Michigan Wolverines and the Georgia Tech Yellow Jackets, the debate focused primarily on whether Willis Ward would be granted the opportunity to play or be withheld because of his race. Officials at the University of Michigan were decisively tight-lipped regarding Ward's status for the game, while Ward's supporters- 


\section{Tyran Kai Steward}

both far and near - engaged in protest against the university, which had been initiated by the swirling rumors of Ward's imminent benching and the reticence on the part of Fielding Yost and Harry Kipke to either confirm or deny those reports. The latter was a part of what Marc Feldman would label as Yost's "do nothing" policy ${ }^{64}$ Nonetheless, Ward had previously been notified during the summer before the school year of his fate- he would not get the chance to play in the game against Tech. The goal was to humiliate Ward, who had obtained a position on the Michigan football team despite Yost's best efforts to maintain racial segregation. ${ }^{65}$

A dejected Ward could not grasp the ferocious intensity of racial prejudice that circumscribed him to such a fleeting fate for the game against Tech. Practice became drudgery, and Ward later declared that his "desire to work was substantially affected." News that Ward was to be sidelined in the game versus Georgia Tech spread rapidly through the campus and the country and invited protests locally and nationally against Michigan's decision to sit their lone black star. These remonstrations, led mainly by students, were aimed directly at prominent athletic and university officials, including Yost, Kipke, and Michigan President Alexander Ruthven.

Various campus organizations, some ultra-left-wing and radical in nature, probed Kipke and Yost for answers, insisting that the reports of Ward's benching be confirmed or refuted. But they took their efforts further, chastising Michigan for its racial connivance in the Ward affair. The Cosmopolitan Club, the National Student League (NSL), the Cooperative House, the John Reed Club, the Michigan League against War and Militarism, the Socialist House, and the Vanguard Club, individually and collectively, wrote letters rebuking Michigan for its collusion. Sonia Smith, writing on behalf of the Cosmopolitan Club, launched a salvo against athletic officers for scheduling the game with an institution that overtly maintained racial segregation. "We, as members of the Cosmopolitan club, believe in racial equality, and therefore, disapprove any action taken by the Board in Control of Athletics in scheduling any event with an institution whose policy involves Racial Discrimination." ${ }^{66}$ The John Reed Club, a Communist Party affiliate, dubbed the potential act of benching Ward as antiAmerican. "We protest the plan of leaving Willis Ward out of the Georgia Tech game. Such racial prejudice is un-American and uncalled for and not in keeping with the standards of the U. of M." ${ }^{67}$ The language of "un-Americanism" was deliberate. Its opposite, "Americanism," enjoyed widespread currency during the 1930s, especially in labor and radical circles. While the term was thought to convey conservative impulses and even a Fordist vision of full participation in the marketplace of American capitalism and was exploited against communist dissidents, the rhetoric of Americanism also imbued the imaginations of nonconformists who gleaned from it inspiration for political revolt. The John Reed Club embraced the progressive dimension of Americanism, connecting their activism and their protest of Ward's benching to the American ideals of "democracy," "freedom," "independence," "liberty," and "rights." In turn, by 
branding the racial prejudice Ward was about to experience as "un-American," the John Reed Club intended to position Michigan as being out of step with-if not in contravention to - the American creed of democracy. ${ }^{68}$

Whereas Smith and the Cosmopolitan Club grilled Michigan's Board in Control of Intercollegiate Athletics for placing the Yellow Jackets on the 1934 calendar, the NSL, another communist-led organization, urged Kipke and Yost to be candid about their intentions. The NSL was accustomed to organizing protests at northern campus communities whenever racist incidents arose. The league jumped at the opportunity to stand up for Ward. "A number of unverified rumors have been circulating around campus to the effect that Willis Ward will be barred from the Georgia Tech game because of the fact that he is a Negro. The National Student League, determined to fight all forms racial discrimination, is naturally concerned. . . Therefore, we respectfully ask you either to verify or deny these rumors within the next two or three days. If such statement is not forthcoming then we shall feel entirely justified in assuming that you have thereby given an automatic verification to the rumors." ${ }^{\circ 9}$ The open letter sent to Yost and Kipke by the NSL's Committee on Discrimination represented only the first ultimatum in a series of coordinated letters written, petitions drawn, and protest demonstrations held by the group. The NSL soon adopted a slogan that became the rallying cry of the Ward movement: "LET WILLS WARD PLAY OR CANCEL THE GAME." $" 70$

Although student-led protest groups stood front and center in the Ward controversy, influential alumni as well as concerned local citizens also criticized the university's decision. To some protesters, their reactions centered on "how such action could be justified in the light of the honor his athletic achievements had already brought to Michigan." ${ }^{.71}$ To others, the response dealt more with the immutable racial injustice that Ward's benching would signify. ${ }^{72}$ As one former alumnus put it, "How could Michigan, such a fine and racially-tolerant institution, allow a Southern school with a different racial standard to dictate its own racial code in the Big House?"'73 This question resonated in a letter sent to the editor of the Michigan Daily by a group of Michigan alumni. These young men declared that "Michigan is democratic. Its history, its tradition, its honor is founded on a bed rock [sic] of education for all those who are capable of getting it, regardless of race, or color, or social and financial position. Those principles are incompatible with the South's position on racial differences." 74

Others in the Ann Arbor community were also riled as word leaked out that Michigan planned to withhold Ward from the competition. A letter to the editor of Michigan Daily echoed the thoughts of Michigan's alumni, faculty, and students who suspected that Ward's benching not only would be regrettable but also would set a bad precedent for the school and other northern institutions if they continued to take a similar approach to tackling racial discrimination. "It will be unfortunate if the Michigan coaching staff, as well as the coaching staffs of other northern universities, concludes that the manner to avoid confrontations of this type in the future is to refrain from coaching and playing promising 
Negro athletic material . . . but the easier and more decent way, both for the students who comprise the University and the people of the State who support that University, is not to schedule games with institutions below the Mason and Dixon [sic] line." 75

The letter to the editor of the Michigan Daily, though admirable, revealed yet another flaw in northern racial liberalism. Its authors, a group of Michigan law students, objectified Ward as "Negro Athletic material" before concluding that "race discrimination was a minor point as compared to the action of the Board in Control of Athletics in this matter." The failure by these students to recognize that race played the most pivotal role in determining Ward's status for the game against Georgia Tech underscored the normalization of racial intolerance amid the supposed commitment to political equality. White moderates overlooked racism as the basis of Michigan's decision to bench Ward and framed the issue as Yost and the Board of Intercollegiate Athletics' unfairness in barring a talented player who had accomplished so much for the team from the game. This "liberal retreat from race," as Stephen Steinberg terms it, was emblematic of the northern version of Jim Crow as white race liberals stood reluctant to identify race as a precipitating factor for racial discrimination. ${ }^{76}$ To pinpoint Ward's race as the origin for the discrimination that occurred might have stirred racial backlash from other African Americans. A letter from Joseph H. B. Evans, an alumnus of Michigan, to Ralph W. Aigler, chairman of the Board in Control of Physical Education, seemed to pronounce a similar warning: "Willis Ward may not play in the game against Georgia Tech, but I prophesy that you and others will see a distinct shattering of team morale . . . and there will be Negro alumni who will accept this as a challenge to fight for the triumph of right and justice in an institution to which they owe allegiance and loyalty." "77 To emphasize the role of race in Michigan's decision would also establish the existence of a northern racial arrangement distinct from southern racial customs. Therefore, these aspiring lawyers focused their message on fairness, on respect for Ward's enormous athletic contributions, and, most notably, on their desire not to see the university set a dangerous precedent for governing race relations in the North.

The North's racial yardstick, however, had already been established by other schools in the region. Michigan was merely following the established pattern of racial exclusion in the North during this era of gentlemen's agreements. Yost was quite aware of this developing tendency to bar African Americans from competitions against southern schools, and there is no question he sought to exploit this racist tradition to disgrace Ward. A year prior to Ward's benching, Yost phoned an associate in Virginia or some other southern state requesting him to arrange a game for Michigan with a Jim Crow school. The Yellow Jackets accepted that overture with the demand that Yost had anticipated. Kendall Wood, son of Professor Arthur Wood, reported the details of Georgia Tech's proposal at a rally held on behalf of Ward. "In December a telegram was received by the Athletic Department from Georgia Tech stating that if Michigan proposed 
to play Ward in the game that it would have to be called off because if Georgia Tech did permit him to play the publicity that Georgia Tech would receive in her local state papers would be so severe that it just could not be allowed." 78

The news from Atlanta pleased Yost, who wanted assurance that Tech officials were unconditionally against any prospect of Ward playing in the game. A friend of Georgia Tech's football coach W. A. Alexander, Yost presumed that a southern school would take the stance of objecting to their teams playing against black players. ${ }^{79} \mathrm{He}$ also received word from his brother-in-law Dan McGugin, football coach at Vanderbilt and a former Michigan football player, that the North's routine of sitting African Americans against southern schools was time honored and would not come under scrutiny. McGugin initially sent correspondences to Yost explaining to him that he could not "afford to use colored players as it has never been done in the case of games with teams from this section." ${ }^{80}$ To further reassure Yost that benching Ward was part of an accepted practice, McGugin cited the recent example of his Vanderbilt team. "Ohio (State) wrote me two years ago about the same thing and I talked with the Board about it and the Board was horrified and was absolutely unwilling to play the game under that condition.... Ohio did not play the man. Ohio told when they scheduled games with the Navy that the Navy asked that a colored man not play at Annapolis but that they did not ask for that agreement at Columbus." ${ }^{\prime 81}$

The black player referenced by McGugin was William Bell, a star tackle on Ohio State's football team. Bell was withheld in a 1930 game against Navy, a decision that Ohio State President George W. Rightmire championed. ${ }^{82}$ When Walter White, secretary of the National Association for the Advancement of Colored People (NAACP), dispatched a telegram to Rightmire protesting the racial prejudice against Bell, the president immediately sent a rejoinder to White suggesting he had never heard of the NAACP and questioning the organization's motives before concluding that "the University is endeavoring to protect him [Bell] from unpleasant experience of probable race discrimination manifested in a southern city." Rightmire alleged that Bell agreed that it was "best that he does not make the trip to Baltimore because of the conditions which he understands he would probably meet there." There was no such difficulty in benching Bell against Vanderbilt. L. W. St. John, the Ohio State director of athletics, provided Yost with all the particulars. "Nothing was said in advance of the Vanderbilt game.... Some time ahead of our game, I had personally talked with Dan McGugin and told Dan not to be disturbed, that we would not play Bell against him. We handled it in such a manner here that the fact that Bell was not put in the game was more or less a surprise to everyone." $" 83$

Yost yearned to do the same with Ward - to go slyly about benching the star without anyone noticing. William Fisch, chairman of the United Front Committee on Ward, a communist-led conglomerate of student organizations, substantiated this at a rally held on Ward's behalf. "Yost thought he could keep Ward out of this particular game and no one would notice." Unfortunately for Yost, even the North's furtive version of Jim Crow was readily identified. A petition 


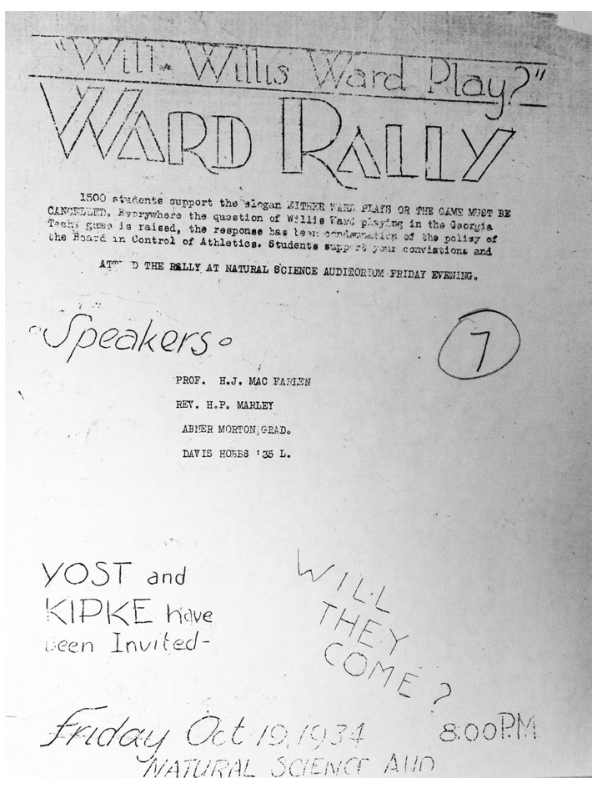

Figure 5: Campus flyer advertising the Ward Rally held in the Natural Science Auditorium on October 19, 1934. Courtesy of Bentley from the Ward United Front Committee against Negro Discrimination read, "Because he is a Negro, Willis Ward is not to be permitted to compete in the Georgia Tech football game. Such a flagrant example of racial discrimination is inexcusable in a university with our cosmopolitan traditions." ${ }^{84}$ But omitted from Fisch's argument that sought to emphasize the school's supposed egalitarian practices was recognition of another maize-and-blue traditionMichigan's egregious history of racial exclusion, especially during the Yost coaching era. Even when African Americans were authorized to play on Michigan teams, they were met with racist caricature, castigation, and contempt. ${ }^{85}$

Ward experienced firsthand Michigan's tradition of racial cruelty. In spite of an outpouring of protests throughout the campus and country, Michigan officials clung to their decision to bench Ward. While Yost was never expected to budge, the clarion call to "LET WARD PLAY OR CANCEL THE GAME" festooned on placards throughout the campus did little to affect the stances of Kipke or Michigan President Alexander Ruthven. Their inaction was not without regret. Ruthven declared to a friend, "My life is being made miserable by arguments with the colored brethren. . . I I wish now that I had taken the Ward matter into my own hands." It was not as if Ruthven did not have the opportunity to do so. Several correspondences mailed directly to him requesting that he get involved were never personally returned to their respective senders. Ruthven admitted that he chose not to answer the letters. As an alternative, he enlisted Ralph Aigler, chairman of the Board in Control of Athletics, to respond to the complaints. ${ }^{86}$

Ruthven's insouciance conflicted with his own feeling that the Board in Control of Athletics should have foreseen the difficulty of scheduling a game with a southern school. He also believed that the Board in Control of Athletics was in error for their role in producing the racial quagmire that caused so much backlash and protest on campus and throughout the community. Ruthven wrote in a letter to A. Richard Frank, "I have convinced myself that the Board in Control of Physical Education invited Georgia Tech to play in Ann Arbor without any thought of Willis Ward ... the Board was in error for scheduling the game 
and should avoid anything of this kind in the future." Ruthven, nevertheless, opted to have Yost and others oversee the matter. "I have not been answering letters received in reference to the Georgia Tech game because the task of selecting players and scheduling games is entirely in the hands of the Board in Control of Physical Education." His frustrations, thus, were self-provoked. Rather than choosing to vocalize his displeasure with Yost's hard-to-miss racism, Ruthven acted aloof. Just as Yost had invited Jim Crowism to encroach on Ann Arbor, Ruthven had done the same through his reticence to espouse the democratic principles that supposedly undergirded the University of Michigan. ${ }^{87}$

Kipke had also been detached from the situation, though his sense of racial apathy was shockingly overlooked by Ward. He absolved Kipke from any blame for the incident, a nod to the latter's willingness to put Ward on the team. "Kipke didn't book the game; he was hurt. And it hurt the image of Michigan, the University of Michigan." His defense of his head coach, perhaps noble, was premised on the way teams prearranged their opponents each season. "The coaches had nothing to do with scheduling ... the last word was the athletic director," Ward averred. It was true that Yost had final say in the matter. But Ward condoned Kipke's silence in failing to address the benching itself. If Yost's actions disappointed Ward, then Kipke's indifference ought to have been a complete letdown. Kipke was considered such a believer in egalitarian ideals that African Americans all across the country sought him out as a reasonable voice to speak against the benching of Ward. In one letter to the coach, W. Rankin Lewis wrote, "Mr. Kipke I will not believe this of you. I know you . . . to be a true sportsman, a man who, when I knew you had no race prejudice whatsoever, but a square shooter all the way. I implore you as a citizen of Michigan, a taxpayer, and we might say a part owner or stockholder in the University of Michigan to recognize the law of Michigan." Rankin tried to appeal to Kipke's sense of fair practice and warned the coach that his failure to act would shift the racial landscape in the North, reversing the strides that African Americans made in the quest for equality. "Give the Black people of Michigan the right to continue to hold up their heads. Give us the right to continue our honest admiration for your courage to use Mr. Ward last year. Do not be the first to bring the Jim Crow rules of Georgia to Michigan." But Michigan was steep in its own racial customs, and Kipke acquiesced fully to those traditions. He was decidedly mute on the arrangement orchestrated by Yost to sideline Ward despite knowing about the plot for almost a year. ${ }^{88}$

Black heads, thus, bowed on October 20, 1934. In a sloppily played, muddy contest, the biggest hits were provided by a bitter Wolverine team led by Gerald Ford, who personally conveyed his resentment for the Michigan-Georgia Tech "gentlemen's agreement" by mauling the Yellow Jackets. Ford was furious at Michigan for surrendering to Georgia Tech's demand and reportedly called the decision to bench his friend and road-trip roommate "morally wrong." Charlie Prescott, a sophomore on the Georgia Tech team, started hurling racial epithets, allegedly referring to the future U.S. president as a "nigger-lover," the 
usually placid Ford lost his temper. Ford, along with another Michigan lineman, Bill Borgmann, slammed Prescott and ended his participation in the game for the remainder of the afternoon. On the following Monday, Ford told Ward that the hit on Prescott was being dedicated to him, cheerfully asserting, "We did that for you!"'90

Short of Ford's hit on Prescott, the game was a quiet affair, and no other spectacular incidents arose. Although there had been rumors of "a sit-down in the middle of the field," the public act of defiance on the part of faculty and students never materialized. The planned "sit-down" was aborted by Fielding Yost, whose resolve it was to prevent any such disturbances from taking place. He first dispatched members of Michigamua, a secret society whose name derived from the racist caricature of the fictional, indigenous Anishnaabe tribe, to the Ward rally held the Friday night preceding the game with the mission to create disorder and to interrupt any plans to organize a sit-down. ${ }^{91}$ Then Yost hired Pinkerton agents to spy on and identify leaders of the Ward movement and to foil any plots by these groups to protest the intersectional contest between Michigan and Georgia Tech. At a rate of fifteen dollars per day plus expenses for the operative detailed, Pinkerton's National Detective Agency agreed to "undertake . . . the investigation of certain matters at Ann Arbor, Michigan." A letter sent to Yost by W. H. Shoemack, Pinkerton's superintendent, expressed gladness in noting "that nothing happened last Saturday" and asked for Yost to indicate whether he was "satisfied with the investigation and result." Yost's racially motivated ploys were successful. ${ }^{93}$ Michigan won the lackluster, rainedout affair 9-2.

For Michigan, the victory was its ninth in eleven tries in an intersectional competition. The triumph, however, wrenched at Big Blue's heart far worse than the two defeats. Members of the varsity, most notably Gerald Ford and Ward, insisted that the Tech game killed the morale of the team. Michigan managed to score only fourteen points the rest of the season - all by Ward in a pitiful performance where Ford, a center, was named team most valuable player. ${ }^{94}$ Yet one alumnus all but treated the lone win of the season as a triumph over Jim Crow. He sent a letter to the team emphasizing the fact that they had prevailed over the South. "Congratulations on your splendid victory over Georgia Tech . . . your defeating them today has certainly put them in their place and taken some of the boastfulness out of them. . . . I've been telling these 'Georgia crackers' that Michigan would win today and they said she didn't have a chance against Tech-but the result goes down in history and Michigan has again conquered the South." 95 Michigan's victory, in reality, was not a conquest over southern Jim Crowism. If anything, the game solidified the North's own discriminatory racial practices. Rather than "put [Georgia Tech] in their place," Michigan demonstrated the national significance of Jim Crow. The Yellow Jackets did make one bizarre concession. In a highly unusual agreement, the team pulled its star end Emmett "Hoot" Gibson from the lineup so that its racial customs could be honored without placing Michigan at a competitive disadvantage. Gibson re- 
portedly never forgave Tech coach W. A. Alexander for making him sit out the game because of a "nigger." "96

In spite of Gibson's benching, Michigan's decision to bar Ward from the game established a pattern whereby northern schools performed the lead role in dictating the national etiquette and colluding with racial exclusion. The gentlemen's agreements that were developed in the early 1900s to provide racial protection for southern teams to avoid any "Negro" surprises on game day, given the lack of specific roster information they possessed about their northern opponents, were now increasingly exploited by northern institutions to rebuff black athletes. Ward was not the only black gridiron star to be benched in a game played northern soil. Dave Myers was forced to the sideline in Yankee Stadium when the University of Georgia visited five years prior to the Ward incident. But in the case of Myers and other black athletes withheld from games in both regions, northern schools, listed them as ill or injured even as these institutions threw in the towel to southern pressure. Yost and Michigan's athletic officials made Ward the first to be banned as a healthy scratch solely on the basis of race. ${ }^{97}$

The final score of the game, thus, was immaterial. Of relevance was the fact that Ward was withheld from the game against Georgia Tech because of Yost's racism and the firmness by Michigan administrators in deferring to the Jim Crow clauses operational at Georgia Tech and throughout the rest of the South. When Yost was unable to impede Ward's participation on the team, he found a southern team to set up a new racial blockade that Ward was powerless to penetrate. If the attempt to Jim Crow Ward was not Yost's rationale for scheduling the contest, it seems strange that he passed up the chance offered by Georgia Tech coach Alexander to call the game off in an effort to save both institutions from any controversy or embarrassment. Why endow Georgia Tech's Jim Crow reputation with national prominence? The same question must have lingered in Roy Wilkins's mind as he protested Michigan's racism. "If this game with Georgia Tech represented a step upward for the University of Michigan's Athletic Department, if it could be regarded as increasing the prestige of Michigan athletics, there might be some ground for Michigan making the great concession of withdrawing its first string end to satisfy Georgia Tech," he stated. "It happens, however, that it is Georgia Tech's prestige which will be increased by a game with Michigan; Michigan's athletic prestige is too firmly established to be enhanced by a game with a second rate institution like Georgia Tech." As Wilkins deduced, the game against Georgia Tech did nothing to advance the University of Michigan. It served only to scale back black progress and to humble Ward, who had broken Big Blue's color barrier that Yost, in some measure, erected. ${ }^{98}$

The determination by both schools to elevate the national status of Jim Crow in America proved costly. The day after the game against Georgia Tech, an editorial ran in the Michigan Daily announcing that "everyone who touched [the Ward affair] did so only to lose in respect and esteem." ${ }^{\text {"99 }}$ None lost more than Ward. In an interview with Ted Talbert of the Detroit Free Press, Ward 
agonized, "I didn't play in that game and . . . it ruined my athletic career."100 Phyllis Manson, a Michigan student, poignantly captured the gravity of Ward's loss. "Georgia Tech refused to play with a Black man on the Michigan team and the University of Michigan was left with a racial dilemma. They solved it, badly in my opinion." 101

Yost, for his part, exhibited no racial remorse in a conversation with Dan McGugin, his brother-in-law, where he disparaged colored organizations and campus student organizations just three days after the game against George Tech. He surmised, "The colored race must be in a bad situation judging from the number of national organizations that are organized to insure racial equality or no racial discrimination." The callousness of Yost's racial politics was not lost on anyone familiar with his teams at the University of Michigan. Ward offered an unsympathetic description of the former coach as a "Southern gentleman with all the attitudes of an aristocrat, but he wasn't an aristocrat." He identified Yost as having a "huckster attitude" and as a person who believed "the game was for white Protestant gentlemen." 102 John L. Griffith, the commissioner of the Big Ten, nonetheless, sympathized with Yost. "You were telling me up at Minneapolis about the radical students organization," referring primarily to the National Student League, which, according to Griffith, "stirred up the rumpus about Ward in the Georgia Tech game. . . Can you without too much trouble advise me whether or not there are any other liberal clubs in Michigan?" According to John Behee, Griffith "apparently wanted to be forewarned in order to stifle any similar actions on Big Ten campuses." 103

Any lingering distress over Kipke's prearranged assault was now a distant memory, supplanted by the unpleasant reality that the road the Ward family had traveled to move far away from the Jim Crowism of the South was meandering. Ward knew that there were only delicate differences to be parsed between the northern and southern racial variety. He emphasized this view in an interview he conducted years later with John Behee. "Much of the racism Michigan men experienced, during the first half of the century, as they worked, studied, socialized and competed for their school," he stressed, "was typical of the Midwest and much of the nation outside the "solid South." "104

\section{Conclusion}

Willis Ward's benching at the University of Michigan in 1934 sheds enormous light on white liberals' efforts to achieve race management during the twentieth-century American interwar period. For Michigan and much of the Midwest, Ward's benching laid bare the ongoing racial inequalities that persisted beyond white northerners' endorsement of racial liberalism. If Ward's participation on the Michigan football team attested to the belief by white race liberals' that all Americans should be politically equal, his benching and the unwillingness by university officials to cancel the game against Georgia Tech exposed the inadequacies of racial policies devoid of state enforcement. The 
irony is that white race liberals distinguished the North as a place where modern forms of racial democracy resided in contrast to the crude and openly sadistic application of segregation as practiced in the Jim Crow South. ${ }^{105}$ But for black athletes, both the North and the South were backward and brutal. Surely, it was a de facto version of Jim Crow. But it was Jim Crow, nonetheless, and it shaped the lives of African Americans in intercollegiate athletics just as it had the broader black community. This de facto Jim Crow can best be understood in the way that Michigan moved forward after the Ward incident. After Ward graduated, it took the university another seven years before another African American was given an opportunity to play football. Julius Franks became the first of only four black athletes to make Michigan's teams in the 1940s; Gene Derricotte, Lenny Ford, and Robert Mann were the others. While these four players doubled the previous number of black football players in the school's history, there were still a number of African Americans who were deprived of the same opportunities. John Behee cites Horace "Hap" Coleman and Joseph Hayden Jr. as two players who were turned away. According to Behee, Coleman "tried to convince Coach 'Fritz' Crisler that he could help the 1945 football team, but was informed they already had one black." ${ }^{106}$ As Behee states, "Unwritten quotas were maintained to keep the number down to one or two superb athletes." 107 They helped to establish a standard regulating black participation through benching, prohibition, or rationing.

Echoes of northern racial liberalism remain. Although this policy of race management failed to remedy discriminatory racial practices, it offered what appeared to be a semblance of racial consensus. Its liberal discourse implied that tolerance was the first step toward building a harmonious, racially equal polity and that segregationist tactics could be eschewed merely through statutory changes. That African Americans were regarded as politically equal mattered more than the corrupt and potent forces that might continue to pursue a cruel variety of racial hierarchy. Given the sordid history of race relations, this system of race management, despite its patterns of letdown, held appeal. For white race liberals, its principle of "tolerance" was both the beginning and the end of their prescription for the problems of African Americans, making only a gradual move toward acceptance and citizenship, each of which would be fulfilled in an indeterminate future. ${ }^{108}$ For some African Americans, northern racial liberalism was better than the de jure segregationist system that had been previously erected despite the fact that it may have led to only symbolic change. Ward partially endorsed this naive view, explaining that "the reality [of racial discrimination] was so massive that all a person of good will could do was make token gestures." ${ }^{109}$ In time, northern racial liberalism, even as a token gesture, has become privileged throughout the nation as the accepted program for race management. As historian Karen Miller argues, "This is the racial system that we have now, where there are no formal legal distinctions among people based on race. Almost all of those are actually illegal." Along these lines, legal and legislative remedies during the 1960s brought a formal end to Jim Crow in 
America. But as morally and politically unacceptable as racism is portrayed, somehow racial inequality endures. The problem, however, is that the permanence of racial inequality is isolated from the legacy of northern institutions of higher education. Present-day racial inequalities, instead, are seen as remnants from the legacy of a segregationist American South. The northern story of racial liberalism, conversely, suggests that "race relationships" have improved as a result of fair athletic competition. Yet the Ward incident illustrates how racial inequalities persist because racism is constantly being politically reinvented. In effect, the integration of black athletes at Michigan may have symbolized racial progress, but substantively it lacked full inclusion. ${ }^{110}$

Further, the ongoing challenges faced by contemporary African American students at the University of Michigan continue to be evidence of the fictivity of northern liberalism. These struggles are best glimpsed in the Black Action Movement strikes - a series of three coordinated protests by black students against the University of Michigan's admissions policies and practices that took place between 1970 and 1987 where black students protested for full inclusion as university students. It also can be observed in the 2003 Supreme Court cases of Gratz v. Bollinger and Grutter v. Bollinger, which provided for a split decision on the use of affirmative action at the University of Michigan. While the Supreme Court upheld the Law School's affirmative action admissions policy, it dismantled the university's predetermined allocation system that awarded twenty points to underrepresented minorities, namely, African Americans, at the undergraduate level. The passage of Michigan Civil Rights Initiative in 2006, legislation that banned the use of race, among other factors, in college admissions, only worsened the general black enrollment at the University of Michigan, causing a 30 percent decline. ${ }^{111}$ Ironically, the university facilitated more black football players on the field than in the general student population. Eighty years after Ward's benching, African Americans at Michigan, in essence, continue to be just as Dan Kean understood them to be in 1934: "At the University but not OF it." It is perhaps this reason that Behee, with Kean clearly in mind, remarked, "He could just as well have been describing 1954 or 1964."112 In truth, Kean also could have very well been describing life at the university for black students today.

\section{Notes}

1. Gunnar Myrdal, An American Dilemma: The Negro Problem and Modern Democracy (New York: Harper \& Row, 1944), 633.

2. John Behee, Hail to the Victors! (Ann Arbor, MI: Ulrich's Books, 1974), 68. The quote came from Dan Kean, who was speaking of his junior and senior years at Michigan (1933 and 1934). Behee followed Kean's quote with a salient reminder of just how far racism and discrimination traveled at Michigan. Behee said of Kean, "He could just as well have been describing 1954 or 1964," casting the vast number of years or, better said, decades black athletes would have to endure racial prejudice at the university.

3. Karen R. Miller, "Racial Liberalism: The Case of Interwar Detroit," Solidarity, accessed July 14, 2016, https://www.solidarity-us.org/site/node/4550.

4. Black students were frequently humiliated by landlords who denied them the chance to rent a place. "We'd go to rent a place and they'd say, 'No, it has just been rented," recalled Lovell 
Farris. But racial intolerance was not left to lodging; it also stretched into campus and classroom life. While black athletes in the first half of the century performed very well academically-Ward, for instance, was an A student in political science - earning postgraduate degrees along the way, many encountered racism from their professors, and not one letterman could ever make the claim they had a black professor during their tenure at Michigan. Lowell Perry recalled a Civil War historian of national prominence who concluded his discourse about the Emancipation Proclamation saying, "Negroes thought it meant freedom from work, a false impression many still have today. They believe all they need is a pork chop and a sunny beach." "That really hurt," Perry remembered. Julian Witherspoon, a track man, also felt shame after he recalled a professor who used the phrase "nigger in a woodpile" to illustrate a point during a lecture. Others could remember hearing stereotypes about black intelligence in spite of their own success in the classroom. Behee, Hail to the Victors!, 54-92; Willis Ward Report Card, Willis Ward Vertical File (WWVF) (this file is housed at the Bentley Historical Collection at the University of Michigan); see also Time, October 29, 1934.

5. "Gentlemen's agreements" refer to the unwritten agreements between athletic officials in the Big Ten to deny blacks the opportunity to play on the basketball team. Nowhere were these gentlemen's agreements more strictly adhered to than in basketball, where blacks were entirely barred. Dan Kean not only believed that gentlemen's agreements were responsible for keeping African Americans off the basketball team but also speculated that the purpose of them was to prevent blacks from rubbing up against whites as that "would be bad . . . they said this could be prevented in football by the uniform worn. Tennis and track were non-contact sports. But in basketball there was too much contact between white skin and black skin" (40).

6. Behee, Hail to the Victors!, 41, 54.

7. Letter, W. A. Alexander to Fielding Yost, January 3, 1934, WWVF.

8. Scholars have taken a comprehensive approach to examining race relations within college sport. Yet this literature focuses primarily on the southern racial order in athletics and provides only negligible attention to racialized dramas that occurred in northern university athletics. Here is a terse sampling: Charles H. Martin, Benching Jim Crow: The Rise and Fall of the Color Line in Southern College Sport, 1890-1980 (Urbana: University of Illinois Press, 2010); Lane Demas, Integrating the Gridiron: Black Civil Rights and American College Football (New Brunswick, NJ: Rutgers University Press, 2011); Andrew Maraniss, Strong Inside: Perry Wallace and the Collision of Race and Sports in the South (Nashville, TN: Vanderbilt University Press, 2014); and Patrick B. Miller, ed., The Sport World of the Modern South (Urbana: University of Illinois Press, 2002).

9. Grace Elizabeth Hale, Making Whiteness: The Culture of Segregation in the South, 1890-1940 (New York: Vintage Books, 1999), 200. In constructing notions of "whiteness" and white supremacy, Hale argues that white southerners established their hegemony through a cultural system based on both physical separation of the races and violence. She contends that this system, which took shape in the 1920s, spread to the rest of the nation. Public spaces became racialized and added new emphasis to the meaning of "whiteness." Like Hale, I am using sport to demonstrate how football operated as a site of inclusion and exclusion, thereby aiding in the segregation of the races and reinforcing the meaning of "whiteness."

10. Although the most overt discriminatory practices have been curtailed, African American athletes continue to suffer from the stereotypes of the mythical black "superspade." The view of black exceptionality today, as it did in the early twentieth century, rests on the belief that African Americans' success in athletics results from innate physical skills rather than determination, hard work, and intellect. These ongoing attitudes reflect the racist categorization of black and white athletes in the past. Whereas white performers were allowed to develop their talents over time, allegedly displaying competency, mental acuity, and work ethic in the process, black athletes had to rely solely on unusual yet intrinsic abilities that substantiated their participation. Modern-day black athletes who excel, as asserted through the lasting myth of the "superspade," do so because they are purportedly more athletic though less intelligent than white athletes. As Timothy Davis argues, "The attribution of success to innate traits reinforces the false belief that black athletes are slothful and obtuse. Conversely, the characterization of the representative white athlete, which is equally false, perpetuates the myth that whites excel in competitive sport in spite of their physical inferiority." For Davis's quote and more on contemporary views of black athletes as "superspades," see Timothy Davis, "The Myth of the Superspade: The Persistence of Racism in College Athletics," Fordham Urban Law Journal 22, no. 3 (1994), 648.

11. Formerly the Western Conference and the Big Nine Conference, the Big Ten Conference was established in 1896. Michigan joined the conference in 1896, replacing Lake Forest College. Indiana did not join the Big Ten until 1899. Ohio State University entered the conference in 1912, in the middle of Michigan's inactivity, which lasted from 1907 to 1916.

12. William McNeil Bell, Biographical File, Ohio State University Archives.

13. Willis Ward, interview by David Pollock, Ford Project, September 8, 1983, 2, Gerald R. Ford Presidential Library.

14. Behee, Hail to the Victors!, 33. 
15. Allison Danzig, The History of American Football: Its Great Teams, Players, and Coaches (Englewood Cliffs, NJ: Prentice Hall, 1956), 155; John Richard Behee, Fielding Yost's Legacy (Ann Arbor, MI: Ulrich's Books, 1971), 17; Scrapbook: "Toast to Yost from Coast to Coast, 1940," Fielding Yost Papers, Bentley Historical Library at the University of Michigan; see also John U. Bacon, Three and Out: Rich Rodriguez and the Michigan Wolverines in the Crucible of College Football (New York: Farrar, Straus and Giroux, 2011), 17.

16. Willis Ward, interview by David Pollock, Ford Project, September 8, 1983, 2, GRFPL.

17. Letter, W. J. Davis to Keene Fitzpatrick, August 17, 1904, Box 1, Board in Control of Intercollegiate Athletics, BHLUM.

18. James Tobin, "The Mystery of Belford Lawson: A Photo, a Family Story, and the Long Shadow of racism," Ann Arbor Observer, October 2009. 1974.

19. John H. O’Brien, "A Black Mark in the Big Blue's Past,” Michigan Chronicle, April 17,

20. John Woodford, “There Was a Time," Michigan Today, December 1988, 10.

21. Willis Ward, interview by David Pollock, Ford Project, September 8, 1983, 1, GRFPL.

22. Patricia Zacharias and Vivian M. Baulch, "Michigan Athletes Have Made Olympic History," Detroit News, February 2, 2002; see also John Woodford, "There Was a Time," Michigan Today, December 1988, 10.

23. Willis Ward, interview by David Pollock, Ford Project, September 8, 1983, 3, GRFPL.

24. Ibid., 2 .

25. "Yost and Wieman Deny Break in Coaching Pact," Los Angeles Times, October 23, 1928.

26. John Sayle Watterson, College Football: History, Spectacle, Controversy (Baltimore: Johns Hopkins University Press, 2000), 177.

27. Behee, Hail to the Victors!, 19; Burton W. Folson, "Governor Groesbeck: Road Builder and Defender of School Choice," Mackinac Center for Public Policy, January 12, 1998; Willis Ward, interview by David Pollock, Ford Project, September 8, 1983, 2, GRFPL.

28. Willis Ward, interview by David Pollock, Ford Project, September 8, 1983, 2, GRFPL.

29. Ibid.; see also Behee, Hail to the Victors!, 19.

30. David Pollock, "The Benching of Willis Ward," Ann Arbor Observer, October 1996.

31. Willis Ward, interview by David Pollock, Ford Project, September 8, 1983, 4-5, GRFPL.

32. Ford purportedly frowned at Michigan's intolerance. He blossomed in America's "Furniture Capital," where he naively observed the manufacturing community to be broad-minded in spite of the overt patterns of racial inequality many African American migrants encountered. Ford insisted that prior to the 1934 season, he had not ever witnessed any racial prejudice, especially not as a child growing up in Grand Rapids. "I treasured the fact that there was no discrimination-you grew up treating everyone equally." Ford poignantly added that he "was dumbfounded that in some parts of even Michigan there were the old, traditional antagonisms toward African-Americans." Far from a closeted bigot, Ford's white privilege groomed him to overlook the racial discrimination. Ford described his Grand Rapids as "a multiracial community" with a proclivity toward racial acceptance. "During my high school years, the Black population was about 13 percent. All public schools and athletic teams were fully integrated ... racial differences had no impact in my personal life or my home community." Ford's account, however earnest, disregarded the racial inequality that hovered over his hometown. Racism inside the southwestern Michigan town was unsightly but far from sightless. Grand Rapids was one of the first cities in Michigan to publicize unequivocally its alarm over black migration to the North. But white northerners expressed their anger beyond periodicals. Barefaced prejudice gripped the community, and the flames of white terror engulfed African Americans, who were secluded into budding ghettoes. In 1919, a Ku Klux Klan outpost was established at South High School, where Ford prepped, and by 1923, the Grand Rapids Herald circulated a history of the Klan to its readers. Two years later, the Klan hosted a weeklong meeting that attracted over 3,000 members in Grand Rapids. No verifiable acts of racial intimidation cropped up during the gathering. The local black community, nevertheless, was keenly reminded of its vulnerability to arbitrary white aggression. For Ford quotes, see David Zeman, "Affirmative Action at U-M: Politics and Principles Collide: Republicans Cox and Ford Have Stark Differences," Detroit Free Press, March 19, 2003, and Gerald R. Ford, "Scrimmaging on the Gridiron and on the Political Front-Personal Narrative on Black and White Race Relations," Ebony, November 1995. For more on the Ku Klux Klan's history in Grand Rapids, see Randal Jelks, African Americans in the Furniture City: The Struggle for Civil Rights in Grand Rapids (Urbana-Champaign: The University of Illinois Press, 2006), 71-72. For more on race relations in Grand Rapids, see Todd E. Robinson, A City within a City: The Black Freedom Struggle in Grand Rapids, Michigan (Philadelphia: Temple University Press, 2012).

33. Willis Ward, interview by David Pollock, Ford Project, September 8, 1983, 4-5, GRFPL.

34. Behee, Hail to the Victors!, 19, 70; Willis Ward, interview by David Pollock, Ford Project, September 8, 1983, 9, GRFPL.

35. Willis Ward, interview by David Pollock, Ford Project, September 8, 1983, 4, GRFPL.

36. Ibid.; James Cannon, Time and Chance: Gerald Ford's Appointment with History (Ann Arbor: University of Michigan Press, 1998), 16. 
37. Ford, A Time to Heal, 50; Cannon, Time and Chance, 16. For more on the construction of Michigan stadium, see "Once Again the Biggest House, 1998, Bentley Historical Library, April 15, 2007, http://bentley.umich.edu/athdept/stadium/stadtext/stad1998.htm (accessed August 11, 2012).

38. Noralee Frankel, Break Those Chains at Last: African Americans, 1860-1880 (New York: Oxford University Press, 1996), 129; Hugh Davis, "We Will Be Satisfied with Nothing Less": The African American Struggle for Equal Rights in the North (Ithaca, NY: Cornell University Press, 2011), 91.

39. "A History of Race and Activism on Campus," Michigan Daily, September 9, 2015; John R. Thelin, A History of American Higher Education (Baltimore: Johns Hopkins University, 2004), 233.

40. Karen R. Miller, Managing Inequality: Northern Racial Liberalism in Interwar Detroit (New York: New York University Press, 2015), 69.

41. Behee, Hail to the Victors!, 79, 84, 89. The absence of blacks on campus also impeded the opportunity for black athletes and nonathletes to forge racial solidarity with one another around the similar cause of racial inclusion. Black athletes and nonathletes supported each other and took pride in any accomplishment that might distinguish them as a race. John Codwell remembered the racial togetherness that African Americans at Michigan demonstrated toward each other, saying of the era, "Black students depended on black students, and for the most part, all of us, athlete and non-athlete" (84).

42. Peggy Pascoe, What Comes Naturally: Miscegenation Law and the Making of Race in America (New York: Oxford University Press, 2009), 169. I cite the years that Michigan's decree against interracial marriage was established and repealed to indicate that miscegenation laws had been disfavored by the state. In spite of this abolishment, the opposition to interracial relationships, specifically interracial sex, continued, and practices proved harder to break than the statutes that gave antimiscegenation its legal teeth. Pascoe notes that by the early twentieth century, state legislators in places like Illinois, Michigan, and New York sought to propose new bans on "marriages between 'Whites or Caucasians,' and any 'African, Chinese, or Japanese'” (163).

43. Willis Ward, interview by David Pollock, Ford Project, September 8, 1983, 8, GRFPL; Associated Press, "Negro Track Star to Seek Football Award: Ward, Detroit Sophomore, After 'M' on Grid at Michigan," The News-Palladium, October 27, 1932.

44. United Press International, "Freshman Star at Michigan," Monessen Daily Independent, May 27, 1932; Cannon, Time and Chance, 19; Associated Press, "Tough Task Faced by Michigan Coach," Washington Daily Chronicle, July 19, 1932.

45. Douglas Owen Baldwin, ed., Sport in North America: A Documentary History. Volume 8: Sports in the Depression, 1930-1940 (Gulf Breeze, FL: Academic International Press, 1992), 163. "Superspade" was the description given to those black athletes who were exceptional enough to earn participation on an athletic team, usually in track and field, at major universities prior to World War II. As John Behee writes, "Superspade and supernigger were the terms used by Muhammad Ali to capture the essence of what was expected of blacks. They had to be sensational." In time, the term was applied broadly to include any African American who was especially gifted in and who had to outperform whites in order to gain inclusion. For Behee's quote, see Behee, Hail to the Victors!, 12 .

46. See Jelks, African-Americans in the Furniture City, 63-78.

47. George Lipsitz, How Racism Takes Place (Philadelphia: Temple University Press, 2011), 124; Joe R. Feagin, The White Racial Frame: Centuries of Racial Framing and Counter-Framing (New York: Routledge, 2010), 2.

48. Miller, Managing Inequality, 99-100.

49. Willis Ward, interview by David Pollock, Ford Project, September 8, 1983, 6, GRFPL.

50. Ibid.

51. Behee, Hail to the Victors!, 68.

52. Ibid., 70 .

53. Ibid., 69.

54. Miller, Managing Inequality, 69, 117.

55. Behee, Hail to the Victors!, 68; Willis Ward, interview by David Pollock, Ford Project, September 8, 1983, 7, GRFPL.

56. Ibid., 7-8.

57. Ibid., 7.

58. James Tobin, "Lonely as Hell," Heritage Project, http://heritage.umich.edu/stories/lonely-as-hell (accessed July 30, 2016).

59. Glenda Gilmore, Defying Dixie: The Radical Roots of Civil Rights, 1919-1950 (New York: Norton, 2009), 189.

60. Kevin Gregg, "Tackling Jim Crow: Segregation on the College Gridiron, 1936-1941" ( $\mathrm{PhD}$ diss., Boston College, 2005), 6. Gentlemen's agreements were not limited to college football. David K. Wiggins points out that these agreements were also employed in sports such as professional baseball and football - the latter of which, according to Wiggins, "allowed some black athletes to participate for a time, but by 1933 it had instituted a Jim Crow clause and become seg- 


\section{Tyran Kai Steward}

regated." Michael McCambridge corroborates Wiggins's claim: “As with major league baseball, pro football was segregated at the time, not by rule or law, but by practice and custom. Numerous blacks had played with the town and factory teams of the league's early years, but since the 1933 season - when the black running back Joe Lillard played for the Chicago Cardinals and a tackle named Ray Kemp saw action with Pittsburgh — not a single black player had received so much as an invitation to training camp, even during the desperate manpower shortages during the war." In addition, the gentlemen's agreements took on other appellations besides "Jim Crow clauses." For example, in professional golf, they were known as the "Caucasian clause." In spite of the sobriquet given to these gentlemen's agreements, they all had the same effect-they were responsible for keeping blacks from participating in either certain games or certain athletics in general. For Wiggins's quote, see David K. Wiggins, Glory Bound: Black Athletes in White America (Syracuse, NY: Syracuse University Press, 1997), 68; for McCambridge's quote, see Michael McCambridge, America's Game: The Epic Story of How Pro Football Captured a Nation (New York: Random House, 2004), 17.

61. Michael Oriard, King Football: Sport and Spectacle in the Golden Age of Radio and Newsreels, Movies and Magazines, the Weekly and Daily Press (Chapel Hill: University of North Carolina Press, 2001), 301.

62. "Color Line in Football," New York Times, November 22, 1903, 13.

63. Oriard, King Football, 301.

64. Marc Feldman, "A Blot on the Michigan Past," Michigan Daily, October 20, 1974. Feldman's accusation that Yost and the Board of Intercollegiate Athletics held a "do nothing" policy hinges on Feldman's belief that Yost was the only official with the authority to cancel the game or insist Ward play. Instead, Feldman contends, Yost chose a taciturn approach that kept many concerned parties on both sides wondering what the final verdict would be on Willis Ward's opportunity to play in the game against Tech.

65. Behee, Hail to the Victors!, 18-19.

66. Letter, Sonia Smith to Board in Control of Athletics, October 22, 1934, Box 20, Board in Control of Intercollegiate Athletics (BCIA) Papers. (These papers are housed in the Bentley Historical Collection at the University of Michigan.)

67. Letter, The John Reed Club to Fielding Yost, October 8, 1934, Box 20, BCIA

68. Gary Gerstle, Working-Class Americanism: The Politics of Labor in a Textile City, 1914 1960 (Princeton, NJ: Princeton University Press, 2002), 6-8, 10; for a larger discussion of Americanism, see Gerstle, Working-Class Americanism, 5-15, 216-18; for a description of its democratic dimension, see Gerstle, Working-Class Americanism, 10, 177-87, 334-35. For a description of "Americanism" as politically conservative and Fordist in nature, see Warren I. Susman, Culture as History: The Transformation of American Society in the Twentieth Century (New York: Pantheon Books, 1984), especially chapters 5, 9-10.

69. Letter, The National Student League to Fielding Yost and Harry Kipke, October 4, 1934, Box 20, BCIA.

70. Bulletin, National Student League, Box 20, BCIA. Although the NSL was a communist affiliate, its initial impetus for the establishment of the group did not emerge from the Communist Party or the Young Communist League. The NSL, instead, began at the City College of New York as a "grassroots" organization. Most of its founding members, predictably, were not communists. As Robert Cohen states, "Among the ghetto-raised students who participated in creating the NSL, it was more common to find youths who had been Left-leaning, but not members of the socialist or communist groups in their pre-college years." Still, Cohen notes that some of these NSL founders "had . . . been groomed for collegiate radicalism by the working class immigrant milieu of their ghetto communities." For Cohen quotes, see Robert Cohen, When the Old Left Was Young: Student Radicals and America's First Mass Student Movement, 1929-1941 (New York: Oxford University Press, 1997), 27, 210.

71. Ibid., 29.

72. In a letter to the editor of the Michigan Daily, H. A. Smith asked, "Are we as a University of supposedly intelligent, broad-minded students, going to permit a team who is evidently not sufficiently liberal-thinking to dictate to us?" Smith was not alone in asking this question as students across the campus and alumni nationwide protested the university's capitulation to the racist laws of the South that called for a separation of the races. For Smith's quote, see Michigan Daily, October 9, 1934.

73. Don Deskins, interview with author, June 20, 2007.

74. Michigan Daily, October 21, 1934.

75. Editorial, Michigan Daily, October 10, 1934.

76. The "liberal retreat from race" argument essentially asserts that when forced to confront the issue of race, liberals will argue that in a racist society, race-based politics are not viable because blacks are an isolated and despised minority. I extend the "liberal retreat from race" argument to encompass incidents where white liberals sought to ignore or lessen the affect that race played in shaping racial separation. For a detailed analysis on the "liberal retreat from race," see Stephen 
Steinberg, ed., Race and Ethnicity in the United States: Issues and Debates (Malden, MA: Blackwell Publishers, 2000), 37-54.

77. Letter, Joseph H. B. Evans to Ralph Aigler, October 17, 1934, WWVF.

78. Kendall Wood, speech at Ward Rally, October 19, 1934, Box 20,BCIA.

79. W. A. Alexander and Fielding Yost were considered to be friends. Records show that the two men often shared company with one another prior to Michigan's game against Georgia Tech. For example, a letter sent to W. A. Alexander from Fielding Yost on February 14, 1934, confirms some degree of relationship between the two men. In the letter, Yost thanks Alexander "for the delightful chicken dinner Saturday and all the other favors extended." For Yost's quote, see Letter, Fielding Yost to W. A. Alexander, February 14, 1934, Box 20, BCIA.

80. Letter, Dan McGugin to Fielding Yost, May 2, 1934, Box 19, BCIA.

81. Letter, Dan McGugin to Fielding Yost, December 12, 1933, Box 18, BCIA.

82. For Rightmire's quote, see Arthur R. Ashe Jr., A Hard Road to Glory: A History of the African American Athlete, 1919-1945 (New York: Warner Books, 1988), 82.

83. Ibid. WWVF.

84. William Fisch, speech at Ward Rally, October 19, 1934, Box 20, BCIA; Poster, n.d.,

85. Earning a roster spot on one of Michigan's athletic teams was hardly a precursor to racial acceptance. For example, George Jewett, Michigan's first black football player, endured physical and vocal harassment with opponents often shouting chants of "Kill the Coon" and "Kill the Nigger" at him during games. These bigoted bellows were drowned out only by the sound of rage being inflicted on Jewett's body. On one play in a game against Purdue, as officials emptied out a number of players from on top of the pile, Jewett was found underneath, flat on his face and unconscious. As his flaccid body was carted off the field, the Purdue fans stood and applauded the efforts of their team to have brought Jewett to his seeming demise. See Kenneth Shropshire, In Black and White: Race and Sports in America (New York: New York University Press, 1996), 25; see also Behee, Hail to the Victors!, 32.

86. Letter, Alexander Ruthven to Shirley Smith, October 12, 1934, Box 16, Alexander Ruthven Papers (ARP), BHLUM.

87. Letter, Alexander Ruthven to A. Richard Frank, October 31, 1934, Box 14, ARP.

88. Ibid., 9; Letter, W. Rankin Lewis to Harry Kipke, September 24, 1934, WWVF.

89. Ford, A Time to Heal, 52-53.

90. Willis Ward, interview by the White House, August 9, 1976, Gerald R. Ford Library, Ann Arbor, MI; see also Black and Blue: The Story of Gerald Ford, Willis Ward, and the 1934 MichiganGeorgia Tech Football Game, directed by Brian Kruger (2011; Detroit: Stunt3 Multimedia, 2012), DVD. The Michigan Daily offered a more sanitized version of Prescott's injury. The paper claimed that "Prescott suffered two broken ribs when accidentally kicked during the second play of the game." See Arthur Carstens, "Jennings Scores on Long Run to Start Michigan toward 9-2 Win over Georgia Tech Eleven," Michigan Daily, October 21, 1934.

91. Behee, Hail to the Victors!, 25. In 2007, Michigamua formally changed its named to Order of Angell to move past its controversial history. In its original identity, the group was censured for its racist practice of imitating Native Americans in public rituals where members dressed in imitation tribal garb. Many Michigamua members had also participated regularly in the black minstrel shows held at Michigan during the early part of the century. The group was founded by Edward "Bob" Parker in 1904 and included among its honorary members Yost, Kipke, and many other toplevel Michigan officials, both in the administration and in the Board of Regents. Yost was such an "active" and important honorary member that the tribe continued to visit his widow for tea every spring on his birthday until her death. The organization's most perplexing member was arguably Gerald Ford. Ford joined Michigamua only a month after Ward was humiliated and banned from Michigan Stadium by Yost. Unlike most members of the 1935 tribe, Ford was not initiated in the spring of that year. The minutes from Michigamua meetings show that he was voted in November 25, 1934, approximately five weeks after Ward's benching, and initiated on December 2. To make matters worse, all votes for membership had to be unanimous. One "black ball," and it is implausible that Ford would have been elected to membership. If Ford's efforts to advocate for Ward were as dynamic as he indicated, his reputation would have been tarnished before the existing Michigamua members, who were clearly hostile to Ward's participation in the game with Georgia Tech that the faction's most cherished member scheduled. For more information on Michigamua, see Douglas M. Smith, "Michigamua/Order of Angell: The Controversial History of Michigan's Skull and Bones Society" (working paper, Faculty of Pathology, University of Michigan, 2012), 44.

92. Letter, W. H. Shoemack to Fielding Yost, October 19, 1934, Box 20, BCIA.

93. Letter, W. H. Shoemack to Fielding Yost, October 27, 1934, Box 20, BCIA.

94. Carstens, "Jennings Scores on Long Run."

95. Letter, D. Kitzinger to Michigan Football Squad, October 20, 1934, Box 20, BCIA.

96. Kruger, Black and Blue, 31 .

97. Ibid., xvii, 25-26.

98. Letter, Roy Wilkins to Harry Kipke, October 11, 1934, WWVF. 


\section{Tyran Kai Steward}

99. Editorial, Michigan Daily, October 21, 1934.

100. Jon Zemke, "Black Athlete Not Allowed to Compete against Georgia Tech," Michigan Daily, April 9, 1999; Ted Talbert, "Moments They'd Like to Forget," Detroit Free Press, September $11,1983$.

101. Letter, Phyllis Manson to the Editor, Michigan Daily, June 1995. Both Georgia Tech and the University of Michigan confronted similar situation some twenty years later. Georgia Tech was preparing to meet the University of Pittsburgh in New Orleans for the 1956 Sugar Bowl. Pittsburgh was adamant that its Negro player, Bobby Grier, participate despite Georgia Governor Marvin Griffin's efforts to prevent the appearance. In a departure from the 1930s, Georgia Tech students strongly opposed the governor's discrimination, and the game was played, making it the first integrated bowl game in the Deep South. In 1953, the University of Michigan played Tulane, another team from the Deep South, and this time, Michigan's black player and all-American tackle Art Walker played in the game. As far as it was known, there was no effort on Tulane's part to have him kept out of the game or even any reference to him in pregame negotiations. For reference to two games played by Georgia Tech and the University of Michigan, see "Georgia's Governor's Action Recalls U-M Case in 1934," Atlanta Journal, January 1956.

102. Feldman, "A Blot on the Michigan Past."

103. Letter, John L. Griffith to Fielding Yost, November 27, 1934, Box 4, FYP.

104. Willis Ward, foreword to Behee, Hail to the Victors!.

105. Miller, "Racial Liberalism."

106. Behee, Hail to the Victors!, 38.

107. Behee, Hail to the Victors!', 36. A reason for the quotas was due, as Behee claims, to the fact that "Michigan football was still big business...it had to be very sensitive to its paying customers, and the customers were certainly not ready for a large influx of black athletes in the 1940s. Neither were the white coaches."

108. Miller, Managing Inequality, 101.

109. Tobin, "Lonely as Hell."

110. Miller, "Racial Liberalism."

111."Black Enrollment Falls 30 Percent at the University of Michigan after Affirmative Action Ban," Think Progress, September 25, 2013, https://thinkprogress.org/black-enrollment-falls30-percent-at-university-of-michigan-after-affirmative-action-ban-65652c5941bd\#.vy8fjyx6g (accessed August 19, 2016).

112. Behee, Hail to the Victors!, 68. 